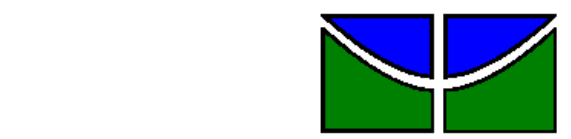

Universidade de Brasília

Faculdade de Economia, Administração e Contabilidade

Departamento de Administração

ANNA PAULA NUNES SVENDSEN PINHEIRO

\title{
IMPLEMENTAÇÃO DO PLANEJAMENTO ESTRATÉGICO NO PODER JUDICIÁRIO: um estudo de caso do Tribunal de Justiça do Distrito Federal e dos Territórios
}

Brasília - DF 


\section{ANNA PAULA NUNES SVENDSEN PINHEIRO}

\section{IMPLEMENTAÇÃO DO PLANEJAMENTO ESTRATÉGICO NO PODER JUDICIÁRIO: um estudo de caso do Tribunal de Justiça do Distrito Federal e dos Territórios}

Monografia apresentada ao

Departamento de Administração como requisito parcial à obtenção do título de Bacharel em Administração.

Professor Orientador: PhD, Ricardo Corrêa Gomes 
Pinheiro, Anna Paula Nunes Svendsen.

Implementação do Planejamento Estratégico no Poder Judiciário: um estudo de caso do Tribunal de Justiça do Distrito Federal e dos Territórios / Anna Paula Nunes Svendsen Pinheiro. - Brasília, 2011. 77 f. : il.

Monografia (bacharelado) - Universidade de Brasília, Departamento de Administração, 2011.

Orientador: Prof. PhD. Ricardo Corrêa Gomes, Departamento de Administração.

1. Planejamento Estratégico. 2. Poder Judiciário. 3. Gestão Pública. 4. Organizações Públicas. I. Título. 


\title{
ANNA PAULA NUNES SVENDSEN PINHEIRO
}

\section{IMPLEMENTAÇÃO DO PLANEJAMENTO ESTRATÉGICO NO PODER JUDICIÁRIO: um estudo de caso do Tribunal de Justiça do Distrito Federal e dos Territórios}

\begin{abstract}
A Comissão Examinadora, abaixo identificada, aprova o Trabalho de Conclusão do Curso de Administração da Universidade de Brasília da aluna
\end{abstract}

\section{Anna Paula Nunes Svendsen Pinheiro}

\author{
PhD, Ricardo Corrêa Gomes \\ Professor-Orientador \\ Esp., Cláudia Oliveira Pinheiro \\ Professor-Examinador \\ Dra., Suylan de Almeida Midlej e \\ Silva \\ Professor-Examinador
}


Dedico este trabalho, primeiramente, a toda minha família, em especial à minha mãe, Rosalba, e ao meu pai, Mário, que sempre foram símbolo de luta, persistência, determinação e encorajamento.

Ao Moacir, pelo amor e companheirismo; por estar sempre comigo, compartilhando todos os momentos; por trazer inspiração a minha vida; e por me fazer alcançar o inalcançável.

Aos meus amigos, próximos e distantes, que conseguem sempre trazer alegria na minha vida. 
A Deus, por me fornecer as condições de ter realizado essa conquista; por me colocar sempre no momento certo e na hora certa em todas as situações; e por me guiar em todo meu percurso.

Ao Tribunal de Justiça do Distrito Federal e dos Territórios, por ter me proporcionado a experiência de estágio e de trabalho de conclusão de curso.

À Universidade de Brasília, pela realização desse sonho.

Aos meus pais, por toda compreensão de minhas ausências para a elaboração do trabalho.

Ao Moacir, pelo constante estímulo, motivação, e paciência, que conduziram a mais uma conquista.

Às minhas amigas queridas da UnB, que estiveram comigo nos momentos bons, mas que durante a monografia se mostraram mais presentes do que nunca.

Aos servidores do TJDFT, por terem auxiliado a minha pesquisa com entrevistas tão enriquecedoras.

Muito obrigada. 
(...) o setor público não está numa situação em que as velhas verdades possam ser reafirmadas. É uma situação que requer o desenvolvimento de novos princípios. A administração pública deve enfrentar o desafio da inovação mais do que confiar na imitação. A melhora da gerência pública não é só uma questão de pôr-se em dia com o que está ocorrendo na iniciativa privada: significa também abrir novos caminhos. (Les Metcalfe e Sue Richards) 


\section{RESUMO}

O presente trabalho aborda o estudo de caso no processo de adoção e implementação do Planejamento Estratégico, em 2007, no Tribunal de Justiça do Distrito Federal e dos Territórios (TJDFT). Esse instrumento representa um processo gerencial de tomada de decisões, definido por meio de estudo do ambiente ao qual a organização está inserida, que permite estabelecer o caminho mais adequado a ser seguido pela instituição para o alcance de um futuro desejado. Com isso, foi traçado o objetivo de pesquisa, que consiste em avaliar o impacto do uso dessa ferramenta nos serviços prestados pelo órgão, de acordo com as perspectivas dos atores envolvidos no processo. A identificação dos atores foi fundamentada de acordo com os níveis organizacionais, de forma a avaliar as diferentes perspectivas da mudança. A metodologia utilizada para a coleta dos dados junto aos participantes foi de natureza qualitativa, com a técnica da análise de conteúdo, por meio de aplicação de entrevistas presenciais e semi-estruturadas. Além disso, foram realizadas análises de dados secundários, com vistas ao exame de documentos e relatórios oficiais do órgão. Dentre os resultados encontrados na pesquisa, vale citar que, desde a implementação do Planejamento Estratégico no órgão, houve avanços substanciais no sentido de promover a continuidade de ações e projetos, além de ter facilitado o alcance dos objetivos estratégicos e de ter proporcionado foco e direcionamento à organização e aos seus colaboradores, impactando na melhoria dos serviços prestados. Contudo, as deficiências constadas no processo incidem sobre a baixa participação dos servidores do nível operacional e sobre a interferência política, que, de certa maneira, prejudicaram a qualidade e a confiabilidade do produto final. A recomendação que se faz, com base nos pontos expostos, é que essas questões sejam devidamente analisadas nas próximas elaborações do Plano Estratégico, não apenas pelo próprio TJDFT, mas também por outras instituições interessadas, de forma que seja possível o comprometimento de toda a organização e que possa prevalecer o conhecimento técnico especializado.

Palavras-chave: Planejamento Estratégico. Poder Judiciário. Gestão Pública. Organizações Públicas. 


\section{LISTA DE ILUSTRAÇÕES}

Figura 1 - Balanced Scorecard em instituições privadas ...................................28

Figura 2 - Balanced Scorecard em instituições públicas .....................................29

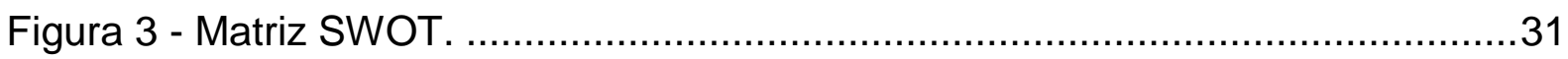




\section{LISTA DE ABREVIATURAS E SIGLAS}

BSC - Balanced Scorecard

$\mathrm{CNJ}$ - Conselho Nacional de Justiça

TJDFT - Tribunal de Justiça do Distrito Federal e dos Territórios 


\section{SUMÁRIO}

$1 \quad$ INTRODUÇÃO

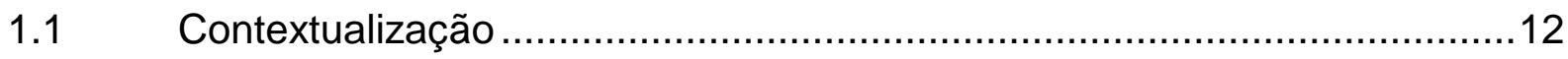

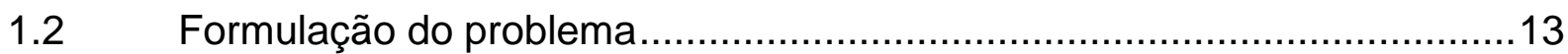

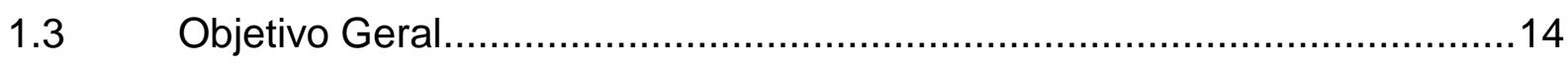

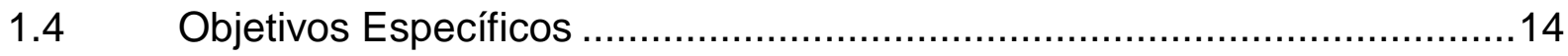

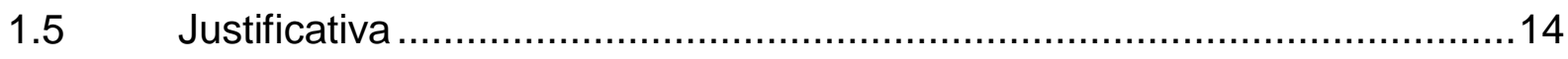

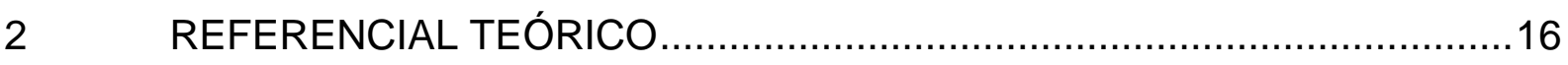

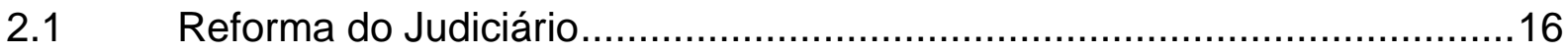

2.1.1 O Conselho Nacional de Justiça...................................................................18

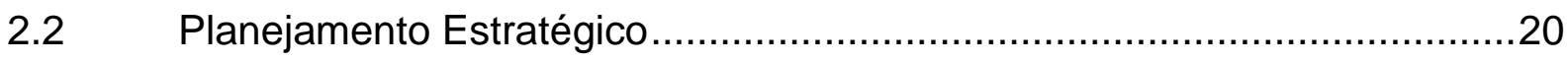

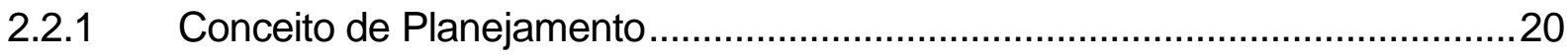

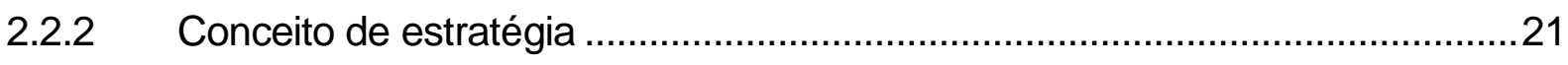

2.2.3 Níveis de Planejamento ............................................................................22

2.2.4 O que é Planejamento Estratégico e qual sua importância? ............................22

2.2.5 O processo de elaboração do planejamento estratégico ................................26

2.2.5.1 O Balanced Scorecard como ferramenta de planejamento ........................26

2.2.5.2 Diagnóstico estratégico ...................................................................29

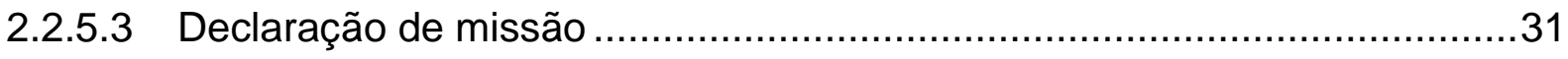

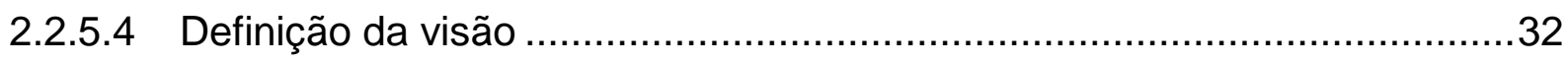

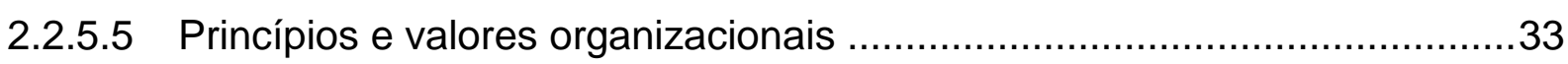

2.2.5.6 Estabelecimento dos objetivos estratégicos ..........................................33

2.2.5.7 Construção das metas e indicadores …………………………….........

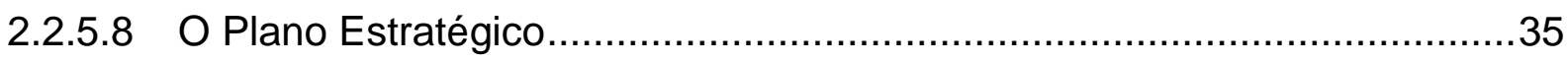

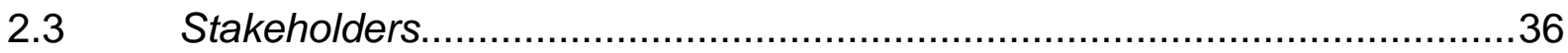

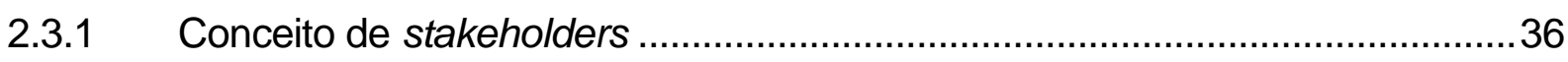

2.3.2 Importância da identificação dos stakeholders na implementação da estratégia. 
2.3.3 O cidadão como foco: novo paradigma da administração pública ..................38

3 MÉTODOS E TÉCNICAS DE PESQUISA ......................................40

3.1 Tipo e descrição geral da pesquisa ............................................ 40

3.2 Caracterização da organização, setor ou área ....................................41

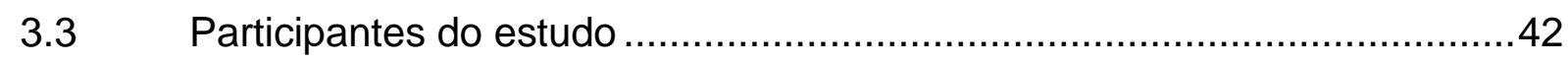

3.4 Caracterização dos instrumentos de pesquisa .....................................43

3.5 Procedimentos de coleta e de análise de dados .................................44

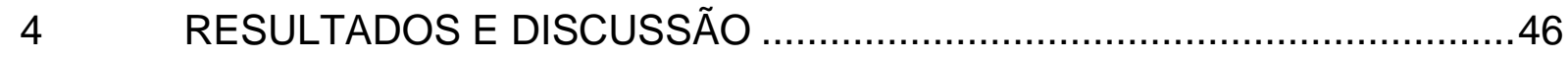

4.1 Processo de implementação do Planejamento Estratégico ........................46

4.2 Grau de conhecimento sobre Planejamento Estratégico e os impactos sentidos pelos servidores .................................................................... 48

4.3 Atuação do Conselho Nacional de Justiça .......................................51

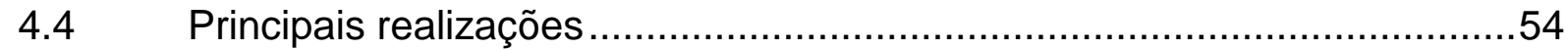

4.4.1 Capacitação de funcionários e otimização de recursos .................................54

4.4.2 Integração entre as unidades organizacionais..........................................55

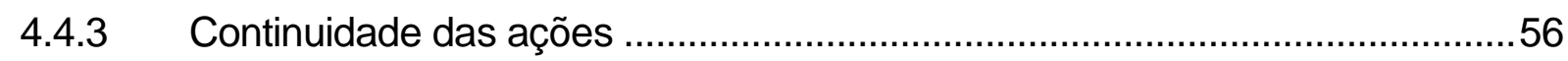

4.4.4 Ações relevantes e infraestrutura ............................................................ 57

S.5 Satisfação dos usuários .................................................................. 57

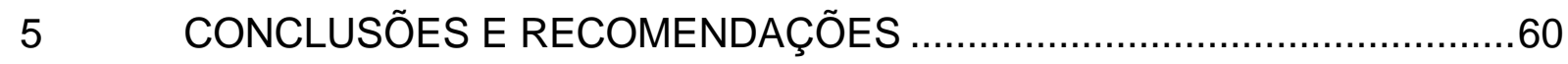

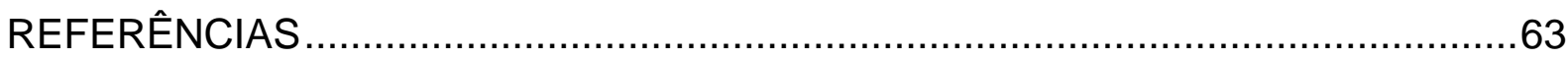

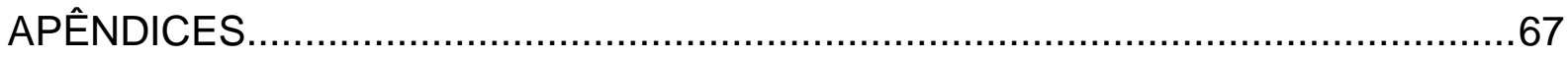

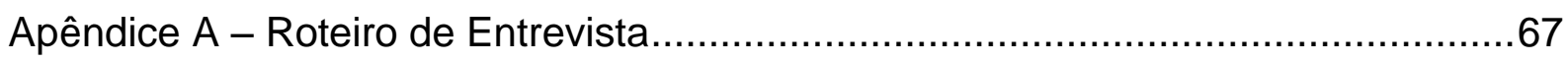

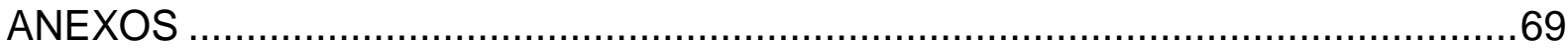

Anexo A - Organograma da Presidência do TJDFT ......................................69

Anexo B - 10 Metas Nacionais de Nivelamento........................................ 70

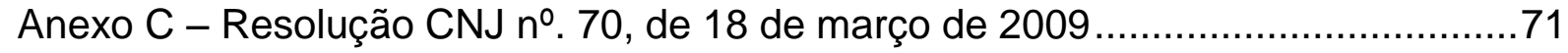

Anexo D - 10 Metas Prioritárias de 2010 ................................................. 77 


\section{INTRODUÇÃO}

\subsection{Contextualização}

Desde a década de 1990, com a evolução dos conceitos de Administração Pública Gerencial, vem se desenvolvendo no Brasil um conjunto de instrumentos de gestão que visa modernizar o Estado e tornar a administração pública mais eficiente e voltada para o cidadão-usuário (BRESSER PEREIRA, 1998). O caráter da administração burocrática, voltada exclusivamente aos interesses do aparelho do Estado, vem sendo abandonado e substituído gradativamente pela prática das novas idéias gerenciais. Sendo o Estado responsável por defender o interesse público, o enfoque dessa nova abordagem passa a ser no atendimento ao cidadão e na melhoria da qualidade dos serviços prestados.

Diante do surgimento desse novo perfil de gestão pública demandado pela sociedade, as soluções que se mostraram mais apropriadas para esse ajuste foram a adoção do Planejamento Estratégico e da gestão estratégica. A implementação dessas soluções, por mais que ainda enfrentem dificuldades de ordem legal e burocrática, tem superado sobremaneira as expectativas.

A criação de um Conselho Nacional de Justiça (CNJ) surgiu da necessidade de viabilizar, no âmbito do judiciário nacional, uma justiça mais célere, eficiente e efetiva, que seja acompanhada de: modernização tecnológica, organização e padronização das estratégias e do planejamento.

Nesse sentido, a publicação da Resolução CNJ n. 70, de 18 de março de 2009, trouxe a obrigatoriedade da elaboração de planejamento estratégico no próprio Conselho e em todos os Tribunais de Justiça do país, de forma alinhada e integrada, para promover uma justiça unificada nacionalmente e que atenda aos anseios da sociedade, buscando conhecer suas reais necessidades.

Verifica-se, portanto, que por mais que o serviço público ainda possua características burocráticas, as mudanças estão acontecendo. $O$ processo de adequação do modelo do Estado Brasileiro despertou para a necessidade de adaptar-se às exigências de ordem econômica e social, reinventando suas práticas e 
princípios e reorganizando sua estrutura, de maneira a acompanhar o desenvolvimento da administração empresarial. Esse é, sem dúvida, um movimento pautado na profissionalização e no aperfeiçoamento da máquina pública.

Diante da nova conjuntura que se encontra o Poder Judiciário Nacional, é de suma relevância o presente estudo de forma a avaliar o impacto do planejamento estratégico na prestação jurisdicional.

\subsection{Formulação do problema}

O Planejamento Estratégico se destaca, também nas organizações públicas, como a solução que melhor atende às demandas da sociedade.

No Tribunal de Justiça do Distrito Federal e dos Territórios, o Plano Estratégico define a estratégia a ser seguida, por meio de um mapa que relaciona cada objetivo e pela elaboração de metas claras. Assim, é possível promover o acompanhamento efetivo da implementação do Plano, de forma a contribuir para que a instituição se torne ainda mais efetiva na prestação dos serviços.

Uma das principais características de um Plano Estratégico é a flexibilidade que permite a constante revisão e reavaliação dos projetos e atividades em andamento. Dessa forma, os ajustes necessários são feitos e acompanhados pelos gestores, possibilitando a revisão de processos, metas e indicadores estabelecidos, sempre com foco na conquista dos objetivos traçados.

Diante disso, foi estabelecida a seguinte situação problemática: como o Planejamento Estratégico possibilitou ao Tribunal de Justiça do Distrito Federal e dos Territórios realizar uma melhor prestação jurisdicional? 


\subsection{Objetivo Geral}

Analisar, a partir da percepção dos atores envolvidos, a influência do Planejamento Estratégico na prestação dos serviços realizados pelo Tribunal de Justiça do Distrito Federal e dos Territórios.

\subsection{Objetivos Específicos}

a) Identificar os atores envolvidos no processo de implantação do Planejamento Estratégico;

b) Analisar como ocorreu a institucionalização do Planejamento Estratégico no Tribunal de Justiça do Distrito Federal e dos Territórios;

c) Averiguar, à luz das percepções dos atores envolvidos, o impacto do Planejamento Estratégico nos serviços prestados pelo Tribunal de Justiça do Distrito Federal e dos Territórios.

\subsection{Justificativa}

O ritmo acelerado das transformações econômicas e sociais ultrapassa a capacidade de atualização da legislação e dos sistemas de apoio à atividade pública, promovendo o desequilíbrio e o conseqüente distanciamento entre a expectativa do cidadão e a capacidade do Estado no atendimento às suas necessidades. A escassez de recursos e as barreiras burocráticas de ordem legal exigem dos gestores públicos habilidade para contornar tais dificuldades e buscar soluções que promovam atendimento satisfatório à população.

Dessa forma, é importante a adoção de instrumentos organizacionais de apoio que viabilizem respostas adequadas e oportunas às demandas apresentadas. A busca pela efetividade na prestação de serviços não deve ser baseada na improvisação, uma vez que expõe ao risco inadequado de recursos e esforços. Sendo assim, faz- 
se necessário desenvolver uma visão sistêmica, perceber a organização como um conjunto de partes articuladas e interdependentes que precisam de uma orientação comum no alcance dos objetivos, preocupando-se, inclusive, em estabelecer parâmetros que permitam avaliar o desempenho organizacional.

Diante disso, é relevante a implantação de metodologia capaz de direcionar os administradores quanto à definição de ações que viabilizem a busca pela excelência. A construção do Planejamento Estratégico no Judiciário proporciona a continuidade das ações e de iniciativas. Já a gestão estratégica, permite que o CNJ possa coordenar ações que auxiliem e alavanquem a gestão administrativa dos tribunais (CHAER; AZEVEDO; BONIFÁCIO, 2009).

A prestação de contas requerida pelos organismos competentes vem se transformando em instrumento de avaliação de resultados, analisando a relação "custo x benefício" de cada ação, que só pode ser dimensionada com ferramentas de medição apropriadas e controle efetivo dos programas e projetos desenvolvidos.

Os resultados do estudo serão importantes para o próprio Tribunal de Justiça do Distrito Federal e dos Territórios, que poderá ter feedbacks, a partir de seus colaboradores, sobre seu processo de implementação de Planejamento Estratégico, e, nesse sentido, promover melhorias de forma a aprimorar a qualidade do uso da ferramenta. Isso acarretará em mudanças substanciais na melhoria dos serviços prestados à sociedade. Não obstante, o estudo de caso será relevante também para os demais órgãos do Poder Judiciário que almejam implementar o Planejamento Estratégico de forma eficaz e efetiva, tendo a participação de seus colaboradores na melhoria contínua do processo.

Espera-se que os resultados provenientes deste trabalho também sirvam para a realização de novos estudos acadêmicos acerca desse tema, subsidiando futuras pesquisas. 


\section{REFERENCIAL TEÓRICO}

A análise do referencial teórico consistiu, primeiramente, em abordar a Reforma do Judiciário no Brasil, ressaltando o grande marco da criação do Conselho Nacional de Justiça. Posteriormente, foi detalhada a metodologia de Planejamento Estratégico, delimitando seus temas de abrangência, suas aplicações e, sobretudo, sua importância no contexto público. Por fim, houve a avaliação da importância dos stakeholders no processo de implementação das estratégias.

\subsection{Reforma do Judiciário}

O Poder Judiciário sempre foi alvo de grandes questionamentos. A lentidão e a ineficiência da prestação jurisdicional, a descontinuidade de iniciativas, planejamento estéril e a falta de investimento em capacitação dos servidores eram características predominantes na área judiciária.

"Estas afirmações vêm corroboradas por pesquisas que demonstram a insatisfação e o descrédito da população com as organizações públicas" (RUSSO, 2009, p. 13) e com a justiça estatal, conforme pode ser verificado, segundo a pesquisadora SADEK (2004), onde

levantamentos de institutos especializados (Vox Populi, Data Folha, IBOPE,
Gallup) mostram que, em média, $70 \%$ dos entrevistados não confiam no
sistema de justiça. Recentes investigações realizadas pelo IDESP (Instituto
de Estudos Econômicos, Sociais e Políticos de São Paulo) apontam que os
indicadores mais gerais são igualmente válidos para setores de elite da
população. Entre os empresários, por exemplo, o Judiciário é muito mal
avaliado, chegando a $89 \%$ os que o consideram "ruim" ou "péssimo", em
termos de agilidade (IDESP, 1996).

As experiências de planejamento em órgãos do judiciário resumiam-se a projetos pontuais e à necessidade de atender às demandas que fossem surgindo. Não havia muito espaço para desenvolver técnicas e ações que fossem voltadas para o desempenho de excelência na administração pública.

Russo (2009, p. 9) aponta que o objetivo final do Poder Judiciário é "a prestação de uma boa jurisdição, solucionando os conflitos", mas que há diversas circunstâncias 
que dificultam o alcance de tal finalidade e que geram morosidade e queda na qualidade dos serviços, tais como "número cada vez maior de demanda, insuficiência de juízes e servidores, legislação processual inadequada, entre outros." (RUSSO, 2009, p. 9).

Conforme pronunciamento do Ministro Nelson Jobim (2004, p. 44) no ato de Posse na Presidência do Superior Tribunal Federal,

a questão judiciária passou a ser tema urgente da Nação. $O$ tema foi arrancado do restrito círculo dos magistrados, promotores e advogados. Não mais se trata de discutir e resolver o conflito entre esses atores. [...] $O$ tema chegou à rua. A cidadania quer resultados. Quer um sistema judiciário sem donos e feitores. Quer um sistema que sirva à Nação e não a seus membros. A Nação quer e precisa de um sistema judiciário que responda a três exigências:

a) Acessibilidade a todos;

b) Previsibilidade de suas decisões; e

c) Decisões em tempo social e economicamente tolerável

Essa é a necessidade. Temos que atender a essas exigências. O poder judiciário não é um fim em si mesmo. [..]. É, isto sim, um instrumento da Nação. Tem papel a cumprir no desenvolvimento do país. [...] É tempo de transparência.

Diante desse contexto é que a sociedade, cada vez mais exigente dos seus direitos, vem se manifestando "no sentido de que sejam definidas e implementadas mudanças que tornem o Judiciário mais rápido, mais eficiente e mais voltado para atender aos anseios da população." (BARACHO, 2002, p. 38). Pode-se dizer que, na atual conjuntura brasileira, essa mudança tão reivindicada pela população está acontecendo. "Está surgindo um novo modelo de gestão pública, orientado para a satisfação do cidadão-usuário, com ênfase na qualidade do serviço e do atendimento; baseado em resultados; mais flexível, menos burocrático e centralizado." (RUSSO, 2009, p. 20).

O marco dessa mudança aconteceu com a aprovação da Emenda Constitucional no 45, de dezembro de 2004, que "trouxe importantes inovações no âmbito do sistema judiciário brasileiro.” (MENDES, 2009, p. 4). Dentre elas, vale citar a inclusão do inciso LXXVIII, do artigo $5^{\circ}$, da Constituição de 1988, segundo o qual: "a todos, no âmbito judicial e administrativo, são assegurados a razoável duração do processo e os meios que garantam a celeridade de sua tramitação". Entretanto, uma das inovações mais substanciais foi a criação do Conselho Nacional de Justiça, "organismo central com atribuições de controle e fiscalização de caráter 
administrativo, financeiro e correicional" (MENDES, 2009, p. 4), de forma a integrar e coordenar os órgãos jurisdicionais do Brasil.

\subsubsection{O Conselho Nacional de Justiça}

O Conselho Nacional de Justiça - órgão de controle administrativo e financeiro do Poder Judiciário - criado em 31 de dezembro de 2004 e instalado em 14 de junho de 2005, surgiu da necessidade de viabilizar, em âmbito nacional, uma justiça mais célere, eficiente e efetiva, que seja acompanhada de: modernização tecnológica, organização e padronização das estratégias e do planejamento.

O órgão é composto por representantes da magistratura, do ministério público, da advocacia e da sociedade civil, e possui o propósito de, mediante ações de planejamento, "realizar a gestão estratégica e o controle administrativo do Poder Judiciário e da atuação de seus membros, visando sua interação e o aperfeiçoamento da prestação jurisdicional." (SUPREMO TRIBUNAL FEDERAL, 2009, p. 14).

Conforme 0 art. 103-B, $\S 4^{\circ}$, da Constituição Federal de 1988, compete ao CNJ as seguintes atribuições (CONSELHO NACIONAL DE JUSTIÇA):

a) na Política Judiciária: zelar pela autonomia do Poder Judiciário e pelo cumprimento do Estatuto da Magistratura, expedindo atos normativos e recomendações;

b) na Gestão: definir o planejamento estratégico, os planos de metas e os programas de avaliação institucional do Poder Judiciário;

c) na prestação de Serviços ao Cidadão: receber reclamações, petições eletrônicas e representações contra membros ou órgãos do Judiciário, inclusive contra seus serviços auxiliares, serventias e órgãos prestadores de serviços notariais e de registro que atuem por delegação do poder público ou oficializado;

d) na Moralidade: julgar processos disciplinares, assegurada ampla defesa, podendo determinar a remoção, a disponibilidade ou a aposentadoria com 
subsídios ou proventos proporcionais ao tempo de serviço, e aplicar outras sanções administrativas;

e) na Eficiência dos Serviços Judiciais: melhores práticas e celeridade: elaborar e publicar semestralmente relatório estatístico sobre movimentação processual e outros indicadores pertinentes à atividade jurisdicional em todo o País.

A Constituição Federal aponta para a necessidade de investimento em gestão no serviço público, principalmente ao incluir entre os princípios da administração pública o princípio da eficiência. O Conselho Nacional de Justiça já vem trabalhando neste sentido, fazendo várias exigências na área administrativa dos tribunais.

Dentre as exigências recentes do CNJ, vale citar as 10 Metas Nacionais de Nivelamento (Anexo B) estabelecidas a partir do II Encontro Nacional do Poder Judiciário em fevereiro de 2009, com o intuito de diminuir as heterogeneidades dos órgãos.

Esse Encontro ainda teve como marco a aprovação da Resolução CNJ n. 70, de 18 de março de 2009 (Anexo C), cujo foco foi no alcance das metas e na estruturação do Planejamento e da Gestão Estratégica no âmbito do Poder Judiciário, "prevendo que o próprio Conselho e os tribunais elaborassem seus respectivos planejamentos estratégicos, alinhados ao Plano Estratégico Nacional, com abrangência mínima de cinco anos, até 31 de dezembro de 2009." (RUSSO, 2009, p. 26).

Essa forma compartilhada de construção do Planejamento Estratégico proporciona maior integração, alinhamento e nivelamento do Judiciário brasileiro na atuação jurisdicional.

Mais recentemente, de acordo com informações do CNJ, o 3ํㅡㄹ Encontro Nacional do Judiciário, ocorrido em fevereiro de 2010, reuniu os dirigentes de todos os segmentos do Sistema de Justiça brasileiro para definir as 10 Metas Prioritárias para 2010 (Anexo D), que foram traçadas visando proporcionar maior agilidade e eficiência à tramitação dos processos, melhorar a qualidade do serviço jurisdicional prestado e ampliar o acesso do cidadão brasileiro à justiça

Desse modo, percebe-se um grande empenho nas atividades desenvolvidas pelo CNJ na "busca incessante da melhoria da gestão administrativa, com a diminuição dos custos e a maximização da eficácia dos recursos" (MENDES, 2009, p. 4), procurando aperfeiçoar a prestação jurisdicional brasileira. 


\subsection{Planejamento Estratégico}

\subsubsection{Conceito de Planejamento}

A definição de planejamento, segundo Matus (1988), está associada à idéia de preparação e controle do futuro desejado a partir do presente, por meio da reflexão sistemática sobre a realidade a enfrentar e os objetivos a atingir.

Diante disso, pode-se dizer que "o planejamento não opera com decisões futuras. Ele opera com o que há de futuro nas decisões atuais" (DRUCKER, 1984, p. 135), logo, os gestores precisam assimilar a idéia de que "a definição do futuro desejado, que é o componente básico e a matéria-prima do planejamento" (BARACHO, 2002, p. 51), relaciona-se com a ação de decidir, hoje, para que a organização esteja preparada para as incertezas do futuro, tomando decisões e realizando ações nesse sentido.

O planejamento é um processo sistemático, constante e contínuo de tomadas de decisões, "cujos efeitos e conseqüências deverão ocorrer em futuros períodos de tempo." (OLIVEIRA, 2006, p. 36). Isso tende a reduzir o grau de incerteza envolvido no processo decisório e a aumentar a probabilidade de êxito no alcance dos objetivos e metas organizacionais, considerando que o planejamento, ainda de acordo com Oliveira (2006), deve ser visto como ações inter-relacionadas e interdependentes e não como um ato isolado.

\footnotetext{
O propósito do planejamento pode ser definido como o desenvolvimento de processos, técnicas e atitudes administrativas, as quais proporcionam uma situação viável de avaliar as implicações futuras de decisões presentes em função dos objetivos empresariais que facilitarão a tomada de decisão no futuro, de modo mais rápido, coerente, eficiente e eficaz (OLIVEIRA, 2006, p. 36).
}

Nesse viés, Carmazen (2008) cita alguns motivos para o uso do planejamento: é preciso que a organização coordene suas atividades de modo integrado; considere a análise do futuro; esteja preparada para o inevitável; tenha opções (planos de ação) frente ao indesejável; controle o incontrolável; e necessite de racionalidade ao adotar procedimentos formalizados, padronizados e sistemáticos.

De acordo com Morais (2009), o planejamento torna-se fator determinante em momentos de grandes mudanças. "As demandas por um Estado mais eficiente, mais flexível, mais democrático e mais efetivo nas suas ações não podem ser 
respondidas com a improvisação" (MORAIS, 2009, p. 12), já que causam prováveis perdas de tempo e de valiosos recursos materiais e humanos, além dos serviços prestados ficarem aquém do esperado. Isso transforma o planejamento e a gestão estratégica em disciplinas básicas para a gestão pública.

\subsubsection{Conceito de estratégia}

Jauch e Glueck (1988) definem a estratégia como sendo um plano unificado, abrangente e integrado, que relaciona as vantagens estratégicas com os desafios do meio envolvente, elaborado de forma que assegure o alcance dos objetivos básicos da organização.

A estratégia é a "arte de aplicar com eficácia os recursos de que se dispõe ou de explorar as condições favoráveis de que porventura se desfrute, visando o alcance de determinados objetivos" (HOUAISS; VILLAR, 2001). Essa definição mostra quão importante é a implementação de uma estratégia nas organizações, visto que se constitui como uma ferramenta capaz de auxiliar a instituição a otimizar seus recursos, mostrar seu diferencial perante a sociedade, reduzir seus problemas e melhor explorar as possíveis oportunidades.

"A finalidade da estratégia é estabelecer quais serão os caminhos, os cursos, os programas de ação que devem ser seguidos para serem alcançados os objetivos e desafios estabelecidos" (OLIVEIRA, 2006, p.192).

Kaplan e Norton (1997) destacam que a estratégia implica no deslocamento de uma organização de sua posição atual para uma posição desejável, porém incerta.

A formulação da estratégia é um dos aspectos mais importantes no processo de elaboração do Planejamento Estratégico, por ter como base os objetivos e desafios estabelecidos na realidade identificada, no diagnóstico estratégico e respeitando a missão, os propósitos e a cultura da organização.

Vale ressaltar que a estratégia, segundo Oliveira (2006), para ser viável, deve ser compatibilizada com os recursos disponíveis, adaptável às possíveis modificações do ambiente e adequada, em termos de consecução dos objetivos propostos pela empresa. 


\subsubsection{Níveis de Planejamento}

A análise do Planejamento Organizacional pode ser vista sob três níveis: estratégico, tático e operacional.

O nível estratégico "relaciona-se com objetivos de longo prazo e com estratégias e ações para alcançá-los que afetam a empresa como um todo." (OLIVEIRA, 2006, p. 45). Representa, ainda, decisões que acarretam em impacto maior, mais profundo e mais duradouro para a organização. Devido ao grau de importância para a empresa, esse nível é, geralmente, de responsabilidade dos níveis hierárquicos mais elevados.

O nível tático, segundo Oliveira (2006), consiste em traduzir os objetivos, estratégias e políticas estabelecidas no planejamento estratégico, em ações a serem desenvolvidas em determinada área ou setor da organização, e não na empresa como um todo. Com isso, devido à menor amplitude de atuação, o nível tático representa decisões de médio prazo e são mais facilmente revistas.

Por fim, o nível operacional é, normalmente, "elaborado pelos níveis organizacionais inferiores, com foco básico nas atividades do dia-a-dia da empresa." (OLIVEIRA, 2006, p. 49). Desse modo, possui visão de curto prazo e corresponde aos planos de ação, aos processos e aos projetos da organização.

\subsubsection{O que é Planejamento Estratégico e qual sua importância?}

O Planejamento Estratégico representa um processo gerencial de tomada de decisões, definido por meio de estudo do ambiente ao qual a organização está inserida, que permite estabelecer o caminho mais adequado a ser seguido pela instituição para o alcance de um futuro desejado. Diz respeito à formulação de objetivos para a seleção de programas de ação e para sua execução, levando-se em consideração as variáveis internas e externas e os resultados esperados.

Diante disso é que Oliveira (2006, p. 47) caracteriza o planejamento estratégico como sendo um "processo administrativo que proporciona sustentação metodológica 
para se estabelecer a melhor direção a ser seguida pela organização", em meio às mutações do contexto em que está inserida, visando ao otimizado grau de interação com o ambiente e atuando de forma inovadora e diferenciada.

De acordo com Chiavenato e Sapiro (2003, p. 39), planejamento estratégico é

\begin{abstract}
um processo de formulação de estratégias organizacionais no qual se busca a inserção da organização e de sua missão no ambiente em que ela está atuando. [...] O planejamento deve maximizar os resultados e minimizar as deficiências utilizando princípios de maior eficiência, eficácia e efetividade. Possui, ainda, o objetivo de proporcionar bases necessárias para as manobras que permitam que as organizações naveguem e se perpetuem mesmo dentro de condições mutáveis cada vez mais adversas em seu contexto de negócios.
\end{abstract}

Já para Drucker (1984, p. 136), planejamento estratégico é

o processo contínuo de, sistematicamente e com maior conhecimento possível do futuro contido, tomar decisões atuais que envolvem riscos; organizar sistematicamente as atividades necessárias à execução dessas decisões e, através de uma retroalimentação organizada e sistemática, medir o resultado dessas decisões em confronto com as expectativas alimentadas.

O pensamento estratégico "busca identificar, num contexto marcado pelas mudanças e pelo conflito entre inúmeros atores, os caminhos capazes de potencializar oportunidades e reduzir riscos para o alcance da missão desejada" (BARRETO; DOSTLER, 2009, p. 15). Além disso, dá aos gestores a fundamentação necessária para a construção de um modelo e de ferramentas gerencias que sejam suficientemente fortes para garantir maior efetividade na gestão das organizações públicas e privadas.

Dessa forma, pode-se dizer que o Planejamento Estratégico, conforme Porto e Belfort (2001), abrange todas as atividades críticas de uma organização e forneceIhes senso de unidade, direção e propósito, facilitando as mudanças necessárias induzidas pelos ambientes interno e externo.

Torna-se, dessa maneira, ferramenta fundamental na gestão moderna, traduzindose em "um modelo de decisões coerente, unificado e integrador" (PORTO; BELFORT, 2001, p. 18), capacitando a organização a dar uma resposta consistente a oportunidades e ameaças externas, e a forças e fraquezas internas, com a finalidade de alcançar e manter um desempenho de excelência.

A integração do Planejamento Estratégico com uma Gestão com foco no conhecimento gerado, disseminado e compartilhado na organização, tem sido ponto central para a sobrevivência das instituições públicas e privadas. 
O planejamento estratégico é uma ferramenta gerencial utilizada com sucesso por organizações públicas e privadas no Brasil e em outros países. Adapta-se naturalmente às características distintas de todo tipo de organização, pois contempla conceitos comuns, numa modelagem gerencial destinada a criar condições para viabilizar objetivos e adequar a direção estratégica aos ambientes de mudança (BARRETO; DOSTLER, 2009, p. 15).

Oliveira (2006) ressalta que o planejamento estratégico deve ser visto como um instrumento capaz de ajudar a empresa a se conhecer e a ter uma visão de futuro, e não como meio de solucionar os problemas.

Considerando que as organizações públicas possuem algumas distinções em relação às instituições privadas, foi que Eck (1994 apud BARACHO, 2002) levantou algumas questões que reportam às prováveis dificuldades a serem encontradas para a aplicação dos processos de planejamento estratégico nas organizações públicas, dentre elas, vale citar:

a) as estratégias das organizações públicas são voltadas para o alcance de objetivos sociais, diferentemente das privadas, que se baseiam na competição ou no lucro;

b) o processo decisório nas organizações públicas, que caracteriza-se pela adoção de normas e procedimentos de conduta bastante rígidos e ritualísticos, segue uma racionalidade distinta da observada nas empresas privadas; e

c) as organizações públicas têm dificuldade para justificar as mudanças repentinas, levando-as à continuidade e à estabilidade, diferentemente das organizações privadas que, por sua natureza, devem constantemente mudar e se adaptar ao ambiente.

De acordo com levantamentos estatísticos realizados pelo Conselho Nacional de Justiça, a Média Nacional de Cumprimento (que inclui os Tribunais Superiores e as Justiças Federal, do Trabalho, Eleitoral, Militar e Estadual) da META 1 Desenvolver e/ou alinhar planejamento estratégico plurianual (mínimo de 5 anos) aos objetivos estratégicos do Poder Judiciário, com aprovação no Tribunal Pleno ou Órgão Especial, das Metas de Nivelamento do Poder Judiciário Nacional de 2009, alcançou o patamar dos $98,60 \%$. 
Entretanto, foram apontadas, pelos representantes dos Tribunais no 3ํㅡorkshop de Gestores das Metas do Poder Judiciário, algumas dificuldades desses órgãos do Poder Judiciário em cumprir a meta, tais quais:

- Falta de engajamento de magistrados e servidores pelo desconhecimento das vantagens da gestão estratégica;

- Falta de conscientização e compreensão sobre a necessidade e utilidade da implantação do planejamento estratégico;

- Pequeno lapso de tempo para a estruturação e construção, pois é um novo paradigma na administração judiciária;

- A rotatividade do pessoal responsável pelo planejamento estratégico quando das mudanças na administração do Tribunal;

- Demora no início do processo de construção do planejamento estratégico;

- Dificuldade na definição dos indicadores locais;

- Falta de cultura de processos de gestão.

Muito embora essas dificuldades apontadas tenham um cunho majoritário de quebras de paradigmas, é notório que a atividade de planejamento proporciona o estabelecimento de uma identidade institucional, com definição clara dos papéis a serem desempenhados e de objetivos e metas a serem alcançados, capacitando a organização a atingir os resultados desejados.

O CNJ ter sido o precursor de ações no sentido de viabilizar que os órgãos do Poder Judiciário construam seus planejamentos estratégicos alinhados nacionalmente, é um grande passo rumo a excelência dos serviços prestados à população. Verificouse a importância das organizações públicas promoverem ações que permitam oferecer respostas adequadas e tempestivas às demandas da sociedade.

A adoção de instrumentos de planejamento, construídos por meio de métodos e técnicas apropriadas, auxilia o administrador público em sua jornada rumo à prestação de serviços à sociedade com eficiência e eficácia e contribui para a racionalização do uso de recursos e a otimização da prestação jurisdicional nos órgãos do Poder Judiciário. 
O Governo Federal, em documento oficial (Comitê Executivo do Governo Eletrônico Casa Civil, 2004) reconhece que o conhecimento acumulado progressivamente pelos servidores e gestores públicos é capital intelectual estratégico do Estado. Cabe às organizações públicas gerir esse capital intelectual, por meio de planejamento estratégico que reverta em benefícios cada vez maiores para os cidadãos.

\subsubsection{O processo de elaboração do planejamento estratégico}

O processo de elaboração do planejamento estratégico é constituído pelos seguintes elementos.

\subsubsection{O Balanced Scorecard como ferramenta de planejamento}

Uma das metodologias inovadoras mais utilizadas para a gestão estratégica é o Balanced Scorecard - BSC, criada pelos professores Robert Kaplan e David Norton (Harvard Business School), e considerada um dos mais importantes avanços da administração nos últimos 70 anos.

O Balanced Scorecard, segundo Kaplan e Norton (1997), é um instrumento gerencial que traduz a missão e a estratégia em objetivos estratégicos, com estabelecimento de metas mensuráveis e das ações a serem realizadas pela organização, e em um conjunto abrangente de medidas de desempenho, organizadas segundo quatro perspectivas diferentes: financeira, do cliente, de processos internos e do aprendizado e crescimento. Ruas (2003), de modo simples, define o BSC como a ponte entre o planejamento estratégico e a gestão estratégica, mostrando claramente essa interdependência dos processos.

Ruas (2003) ressalta que é importante que haja um correlacionamento das ações entre si numa cadeia de causa e efeito, considerando as quatro perspectivas, de modo a identificá-las no alcance de cada objetivo estratégico. Logo, o BSC não deve ser utilizado como um sistema de controle ou como um "simples guia para a criação 
de indicadores" (RUAS, 2003, p. 3), mas sim como um sistema de comunicação, informação e aprendizado, e sobretudo, como uma nova filosofia gerencial.

O Scorecard cria uma estrutura, uma linguagem, para comunicar a missão e a estratégia, e utiliza indicadores para informar os funcionários sobre os vetores do sucesso atual e futuro. Ao articular os resultados desejados pela empresa com os vetores desses resultados, os executivos esperam canalizar as energias, as habilidades e os conhecimentos específicos das pessoas na empresa inteira, para alcançar as metas de longo prazo. (KAPLAN; NORTON, 1997, p. 25)

Apesar de o BSC possuir uma abordagem, basicamente, para instituições privadas, percebe-se um grande movimento no sentido de organizações públicas também adotarem essa ferramenta de gestão, atentando-se para algumas adaptações:

a) Perspectiva Financeira: de acordo com Kaplan e Norton (1997), essa perspectiva, no setor privado, indica se o desempenho financeiro alcançado foi aquele esperado, ou seja, relaciona-se estreitamente com o lucro obtido. Já no setor público, a perspectiva financeira, como assinala Ruas (2003), é vista como um fator restritivo, devido ao orçamento fixo, devendo, portanto, enfatizar os aspectos que forneçam maior eficiência na gestão de custos, mas que agreguem, também, o máximo de valor para a sociedade;

b) Perspectiva do Cliente: Kaplan e Norton (1997) consideram que a perspectiva do cliente consiste na identificação dos segmentos de clientes e mercados que a organização atua e presta serviços, onde mede-se, sobretudo, a satisfação dos consumidores e sua fidelização. Nessa linha de raciocínio e aplicando na administração pública, "os clientes e a sociedade em geral são os principais interessados e a razão de ser do setor público, portanto devem ser os balizadores de toda e qualquer ação." (RUAS, 2003, p. 7). Pedro (2004) ainda complementa com a idéia de que a perspectiva cliente além de emergir da missão, ainda sobe de nível, relativamente ao BSC aplicado a empresas privadas. Verifica-se, portanto, que a responsabilidade para com a sociedade é muito maior em empresas públicas;

c) Perspectiva de Processos Internos: essa perspectiva, segundo Ruas (2003), tem como base a análise dos processos internos da organização, identificando os que são críticos para a satisfação dos clientes. Consiste não apenas no monitoramento, mas também na identificação de novos processos que agreguem valor ao cliente. 
d) Perspectiva de Aprendizado e Crescimento: Kaplan e Norton (1997, p. 29) identificam essa perspectiva como "a infra-estrutura que a empresa deve construir para gerar crescimento e melhoria a longo prazo". Segundo Ruas (2003), essa perspectiva aborda a capacitação dos funcionários e alinhamento organizacional. É de suma importância no setor público atualmente, devido à reforma do Estado.

A metodologia utilizada para a elaboração do Planejamento Estratégico Nacional foi - Balanced Scorecard (BSC) que permite ao CNJ avaliar a consecução dos objetivos estratégicos de cada órgão, por meio de indicadores de desempenho, e monitorar os resultados de cada órgão.

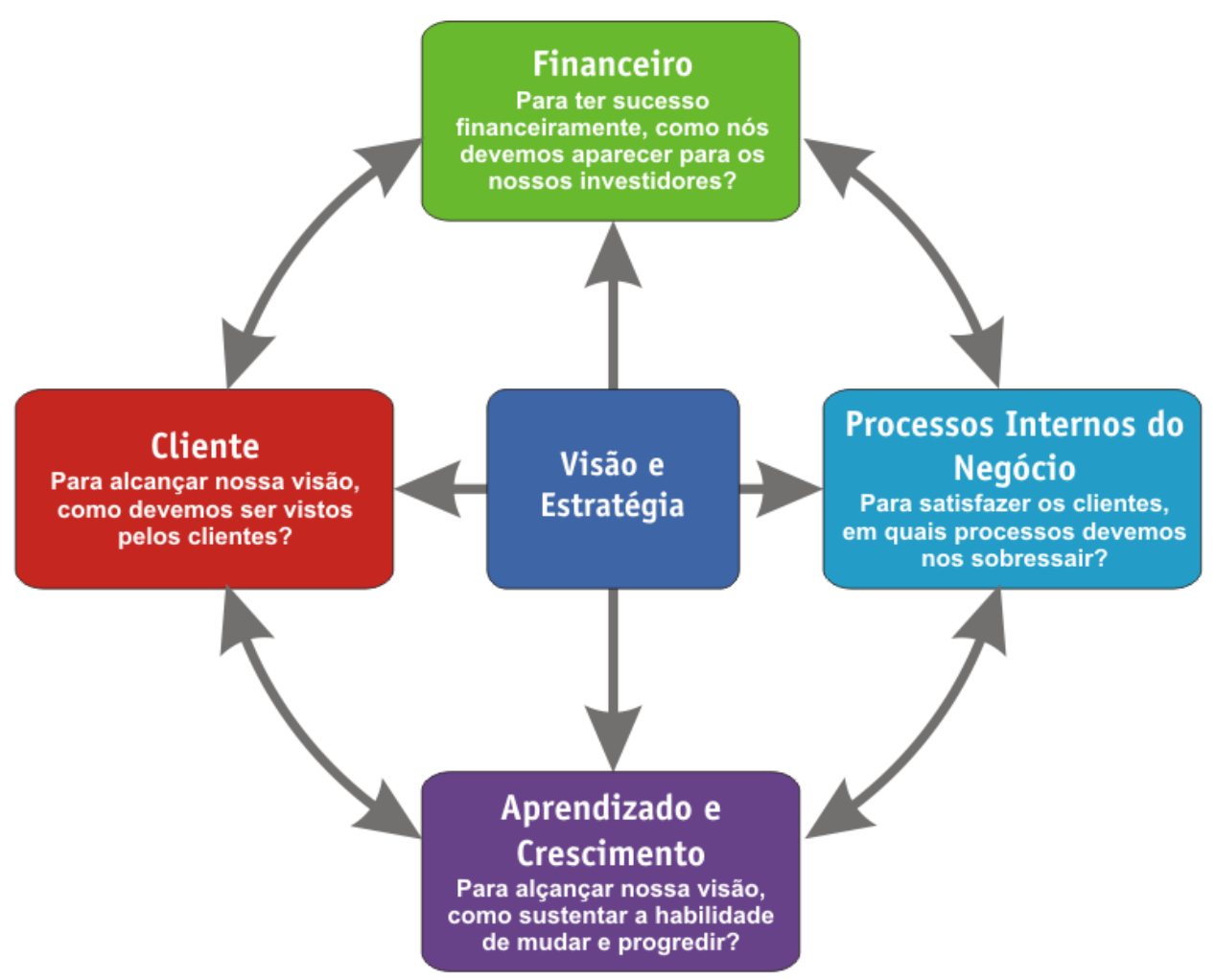

Figura 1 - Balanced Scorecard em instituições privadas Fonte: http://armazemdapublicidade.blogspot.com 


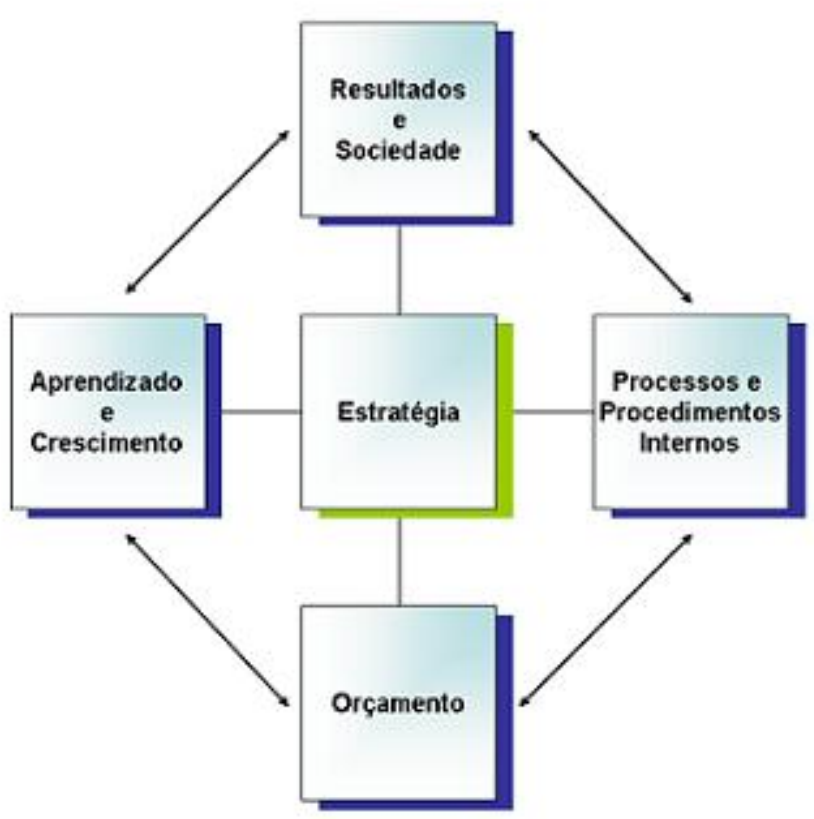

Figura 2 - Balanced Scorecard em instituições públicas

Fonte: http://www.trt23.gov.br/conhecaotrt/planejamento/Metodologia.asp

\subsubsection{Diagnóstico estratégico}

O diagnóstico estratégico corresponde à primeira fase do processo de planejamento estratégico e consiste em analisar a situação atual em que se encontra a organização, tanto no seu ambiente externo quanto no interno. O objetivo dessa etapa no planejamento estratégico incide sobre a hipótese de que é necessário, primeiramente, conhecer o posicionamento da instituição, para que, posteriormente, seja possível traçar objetivos a serem alcançados e criar "condições para a formulação de estratégias que representam o melhor ajustamento da organização no ambiente em que atua." (CHIAVENATO; SAPIRO, 2003, p. 42). Isso proporciona alinhamento e sintonia entre a instituição e o ambiente.

Uma das ferramentas mais utilizadas para realização desse diagnóstico estratégico, a Matriz SWOT, foi criada por dois professores da Harvard Business School - Kenneth Andrews e Roland Cristensen. Ela é composta pela análise do ambiente externo (oportunidades e ameaças) e do ambiente interno (forças e fraquezas) da organização, onde a sigla SWOT, originada do idioma inglês, significa: Forças 
(Strengths), Fraquezas (Weaknesses), Oportunidades (Opportunities) e Ameaças (Threats).

O objetivo dessa análise dos ambientes é de tentar estabelecer/construir uma visão da situação atual e das perspectivas de evolução provável dos ambientes externo e interno à organização, buscando antecipar oportunidades e ameaças ao desempenho organizacional, bem como seus pontos fortes e pontos fracos (MORAIS, 2009, p. 19).

Importante ressaltar que essa análise ambiental consiste, também, na identificação e na análise dos stakeholders (partes interessadas, que podem influenciar ou serem influenciadas pela organização), como forma de serem mapeadas as suas demandas e expectativas sobre o desempenho organizacional.

A análise do ambiente externo aborda o meio em que a organização está inserida, bem como as variáveis relevantes, na perspectiva organizacional, visando identificar as oportunidades e as ameaças existentes, que, dentre outras, consistem em monitorar "forças e tendências de natureza política, tecnológica, econômica, social e educacional" (BARACHO, 2002, p. 63).

De acordo com Oliveira (2006), oportunidade é variável do ambiente não controlável pela empresa, mas que pode criar condições favoráveis à ação estratégica da organização, desde que conhecida e aproveitada, satisfatoriamente, enquanto perdura.

As oportunidades são situações, tendências ou fenômenos externos à organização, atuais ou potenciais, que podem contribuir em grau relevante e por longo tempo para a realização da sua missão ou objetivos permanentes e/ou para o alcance de um bom desempenho competitivo. (PORTO; BELFORT, 2001, p. 30, grifo nosso)

Já as ameaças, segundo Oliveira (2006), são as variáveis externas não controláveis pela organização, capazes de criar obstáculos a sua ação estratégica, mas que poderão ou não ser evitadas, desde que conhecidas em tempo hábil.

As ameaças são situações, tendências ou fenômenos externos à instituição, atuais ou potenciais, que podem prejudicar substancialmente e por longo tempo o cumprimento da sua missão ou dos seus objetivos permanentes e/ou para o alcance de um bom desempenho. (PORTO; BELFORT, 2001, p. 30, grifo nosso).

Em contrapartida, a análise do ambiente interno faz um diagnóstico dos pontos fortes e fracos dentro da própria organização, incidindo sobre "os recursos organizacionais, os seus processos de trabalho e a sua performance, ou seja, os resultados que a organização está sendo capaz de produzir" (BARACHO, 2002, p. 63). 
De acordo com Porto e Belfort (2001), as forças são fenômenos ou condições internas, capazes de auxiliarem, substancialmente e por longo tempo, o desempenho e cumprimento da missão e dos objetivos estratégicos, além de propiciarem uma condição favorável para a empresa em relação ao seu ambiente.

As fraquezas, por outro lado, são situações, fenômenos ou condições internas, que podem dificultar a realização da missão e do cumprimento dos objetivos, promovendo uma condição desfavorável para a organização em relação ao seu meio.

\begin{tabular}{|c|c|c|c|c|c|c|c|}
\hline \multirow{3}{*}{\multicolumn{2}{|c|}{ Ambiente Interno }} & \multicolumn{6}{|c|}{ Ambiente Externo } \\
\hline & & \multicolumn{3}{|c|}{ Oportunidades } & \multicolumn{3}{|c|}{ Ameaças } \\
\hline & & 01 & $\mathrm{O} 2$ & $\mathrm{O3}$ & A1 & $\mathrm{A} 2$ & A3 \\
\hline \multirow{3}{*}{ 芯 } & Força 1 & \multirow{3}{*}{\multicolumn{3}{|c|}{$\begin{array}{l}\text { Potencialidades de } \\
\text { Atuação Ofensiva }\end{array}$}} & \multirow{3}{*}{\multicolumn{3}{|c|}{ Capacidade Defensiva }} \\
\hline & Força 2 & & & & & & \\
\hline & Força N & & & & & & \\
\hline \multirow{4}{*}{$\begin{array}{l}\mathscr{n} \\
\mathbb{N} \\
\mathbb{N} \\
\frac{5}{\pi} \\
\frac{\pi}{4}\end{array}$} & Fraqueza 1 & \multirow{4}{*}{\multicolumn{3}{|c|}{$\begin{array}{c}\text { Debilidade de Ação } \\
\text { Ofensiva }\end{array}$}} & \multirow{4}{*}{\multicolumn{3}{|c|}{ Vulnerabilidades }} \\
\hline & Fraqueza 2 & & & & & & \\
\hline & Fraqueza 3 & & & & & & \\
\hline & Fraqueza $\mathrm{N}$ & & & & & & \\
\hline
\end{tabular}

Figura 3 - Matriz SWOT.

Fonte: elaborada pelo autor.

\subsubsection{Declaração de missão}

A missão, segundo Oliveira (2006), se constitui como declaração básica da razão de ser da organização e é a determinação do motivo central de sua existência. Além disso, corresponde a um horizonte dentro do qual a empresa atua ou poderá atuar.

"A missão é uma declaração de propósitos ampla e duradoura que individualiza e distingue o negócio e a razão de ser da instituição em relação a outras do mesmo tipo" (PORTO; BELFORT, 2001, p. 25).

Sendo assim, é uma afirmação de longo prazo das finalidades de uma organização, que identifica o escopo de sua atuação e reflete seus valores e prioridades. Além disso, ainda ajudará a instituição a tomar decisões consistentes, motivar, construir uma unidade organizacional, integrar objetivos de curto e de longo prazo e melhorar a comunicação. 
Na definição da missão organizacional, procura-se "determinar qual o negócio da empresa, por que ela existe, ou, ainda, em que tipos de atividades a empresa deverá concentrar-se no futuro" (OLIVEIRA, 2006, p. 126).

Desse modo, é relevante que a organização busque definir e explicitar a missão organizacional a todos os envolvidos, delimitando as funções a desempenhar e as necessidades a atender.

Baracho (2002) assinala que a definição da missão organizacional em órgãos públicos significa identificar as necessidades sociais e/ou políticas que deverão ser atendidas pela organização. Nesse sentido, "a atenção para as necessidades dos stakeholders, é a chave do sucesso das organizações, sobretudo na área pública" (BARACHO, 2002, p. 63), assim, é oportuno dizer que a existência de uma missão socialmente aceitável é uma importante fonte de inspiração para os stakeholders, especialmente os internos.

\subsubsection{Definição da visão}

A visão organizacional "é o sonho acalentado pela organização. Refere-se àquilo que a organização deseja ser no futuro." (CHIAVENATO; SAPIRO, 2003, p. 64).

Ela, nada mais é do que o "conjunto compartilhado de intenções estratégicas, desafiantes" (PORTO; BELFORT, 2001, p. 38) para a organização ou a construção de um estado futuro e ambicioso e de direcionamento a longo prazo para a empresa, que possam conduzir com maior coerência os processos decisórios. Por isso, podese dizer que a visão é um elemento importante para a definição dos objetivos estratégicos pretendidos, pois faz com que a organização atue eficientemente e proporcione grande "delineamento do planejamento estratégico a ser desenvolvido e implementado pela empresa" (OLIVEIRA, 2006, p. 88).

Porto e Belfort (2001) e Barreto e Dostler (2009) ressaltam que o grande propósito em se definir a visão de futuro para a organização é o de criar uma imagem que inspire, desafie e mobilize todas as pessoas envolvidas no âmbito organizacional.

Em uma breve comparação entre a missão e a visão, o que se observa é que enquanto a missão delimita a atuação da organização e tem caráter permanente, a 
visão é a busca da excelência no cumprimento da missão, em determinado período de tempo (SANTOS, 1997 apud MORAIS, 2009).

\subsubsection{Princípios e valores organizacionais}

Consistem no conjunto de conceitos, filosofias e crenças gerais compartilhadas pelos funcionários e que "a organização respeita e emprega e está acima das práticas cotidianas, na busca de ganhos de curto prazo. São os ideais eternos, servindo de orientação e inspiração para todas as [...] pessoas da organização." (CHIAVENATO; SAPIRO, 2003, p. 69).

Os princípios, segundo Chiavenato e Sapiro (2003), fazem referência à ética e à honestidade, ou seja, conceitos que não se pode abrir mão, estão intrínsecos na organização, possuem caráter amplo e duradouro e "constituem parâmetros básicos [...] que deverão balizar as práticas da instituição" (PORTO; BELFORT, 2001, p. 28). Já os valores, remetendo-se a Chiavenato e Sapiro (2003), são os atributos e as virtudes da organização, como prática da transparência, cultura para qualidade, dentre outros.

\subsubsection{Estabelecimento dos objetivos estratégicos}

Oliveira (2006) define os objetivos estratégicos como o estado, situação, alvo ou resultado futuro quantificado, com prazo estabelecido, que a empresa pretende alcançar. O autor ainda acrescenta que, para o planejamento estratégico da organização ser eficiente, eficaz e efetivo, os objetivos precisam ser conhecidos, adequados, aceitos e consistentes.

Ramadam (2001, p. 37) destaca que a formulação de objetivos implica em "rever e compreender a visão da organização e, em seguida, estabelecer objetivos que traduzam essa visão em termos concretos". Os objetivos estratégicos, formulados em termos qualitativos, são grandes desafios institucionais elaborados para aproveitar oportunidades ou mitigar ameaças. 
De acordo com Morais (2009, p. 28), "os objetivos estratégicos devem constituir situações-objetivos coerentes com a missão, visão, postura estratégica", bem como do diagnóstico do ambiente interno e externo da organização.

Oliveira (2006, p. 169) afirma que os objetivos são definidos, tendo por base as

expectativas com relação às futuras condições do ambiente externo à empresa, as necessidades da empresa percebidas no momento da definição dos objetivos, assim como as restrições decorrentes das limitações dos recursos à disposição da administração da empresa.

Porto e Belfort (2001) assinalam, ainda, que os objetivos estratégicos são caracterizados por serem: aceitáveis (consistentes com os valores organizacionais), flexíveis (adaptar-se às mudanças imprevistas nos seus ambiente interno ou externo), mensuráveis (suscetíveis a avaliações que indiquem o alcance do objetivo, mesmo que em escalas qualitativas), motivadores (suficientemente ambiciosos para representar um desafio a ser alcançado, mas não algo que pareça impossível ou facilmente atingível), sintonizados (alinhados com a missão e visão organizacional), inteligíveis (formulados de forma clara, concisa e auto-explicativa) e alcançáveis (possíveis e factíveis de realizar no prazo estabelecido).

A importância dos objetivos estratégicos concerne no fato de proporcionarem senso de direção, guiarem os planos e decisões, focalizarem os esforços dos funcionários e ajudarem a avaliar o progresso da organização rumo a excelência.

\subsubsection{Construção das metas e indicadores}

A formulação de indicadores e metas é importante por fazer relação com a avaliação de desempenho e de possíveis feedbacks do processo.

Oliveira (2006) define as metas como as etapas para alcançar os objetivos, sendo vistas, portanto, como as frações dos objetivos. Elas representam as ações concretas, o esforço para chegar ao destino. É fundamental que a estipulação das metas sejam passíveis de execução e de avaliação.

É importante ressaltar que um objetivo não se resolve com apenas uma meta. Depois de traçados os objetivos estratégicos, é necessária a indicação de metas (mensuráveis) para que esses objetivos, a longo prazo, sejam atingidos. 
Ruas (2003) assinala que a maneira de quantificar em metas mensuráveis a estratégia ocorre por meio de um conjunto de indicadores-chave de desempenho.

Os indicadores são sinalizadores de alcance de uma situação ou estado desejado. Podem ser traduzidos em números, percentuais, descrições de processos ou fatos que indiquem a mudança qualitativa e/ou quantitativa de uma condição específica. Devem demonstrar, claramente, o que das ações ou processos desenvolvidos tem-se como resultados possíveis de perceber, medir, qualificar e avaliar. (ZIMMERMANN, 2003, p. 34).

Ruas (2003, p. 8) enfatiza que o estabelecimento dos indicadores deve "deixar clara a ligação entre as ações a serem implementadas e a estratégia do negócio, além de monitorarem o andamento da estratégia". Desse modo, ainda de acordo com o autor, é preciso ter atenção e cuidado para a escolha dos indicadores, considerando que devem ser visualizados apenas como medidores de eficácia e de monitoramento do alcance dos objetivos, e não como indicativo de boas estratégias.

O estabelecimento de parâmetros que permitem a mensuração dos objetivos pretendidos faz com que a Administração possa efetivamente incrementar sua gestão. (CHAER; AZEVEDO; BONIFÁCIO, 2009).

\subsubsection{O Plano Estratégico}

O Plano Estratégico é o produto obtido com o processo de planejamento, é a materialização de todo o esforço do processo de planejamento estratégico empreendido pela instituição. Pode ser considerado como um "conjunto coerente de grandes prioridades e de decisões que balizam o desenvolvimento e a construção do futuro de uma organização num horizonte de longo prazo." (PORTO; BELFORT, 2001, p. 15). Por isso, converte-se em ferramenta gerencial básica para se assegurar racionalidade ao processo decisório, fazendo convergir os esforços e as ações de uma determinada organização.

Segundo Porto e Belfort (2001), a transformação do plano estratégico em documento escrito é importante, tanto no que se refere à difusão das idéias propostas, como na possibilidade de seu uso como ferramenta de apoio à gestão estratégica da organização, funcionando como uma agenda para os dirigentes. 


\subsection{Stakeholders}

\subsubsection{Conceito de stakeholders}

Stakeholders, de acordo com Freeman e Reed (1983 apud CANCELLIER, 2000), possui dois tipos de definição: o de sentido amplo, que é qualquer grupo ou indivíduo que pode afetar a consecução dos objetivos da organização ou que pode ser afetado por esses objetivos, e o de sentido estrito, que envolve qualquer grupo ou indivíduo, com interesses e expectativas, que a organização depende para sobreviver. Thompson et al. (1991 apud ALMEIDA; FONTES FILHO; MARTINS, 2000), em relação ao conceito de sentido amplo, complementam caracterizando os stakeholders como qualquer ator que possua algum tipo de relação ou interesse com ou sobre a organização.

Oliver (1991 apud GOMES, 2005) aponta que uma organização, como entidade de sistema aberto, é razoavelmente influenciada pelas pessoas, grupos e outras organizações, cuja influência é fundamental para o processo decisório da instituição.

A identificação desses atores interessados e/ou beneficiários do êxito da organização ocasiona na viabilização de modelos de gestão organizacional em bases mais sustentáveis (BARACHO, 2002).

As proposições de análise de stakeholders exigem uma completa compreensão
e conhecimento de todos os stakeholders (no sentido amplo) de uma
organização e seu poder de influência na vida organizacional. Isso significa que
o administrador deve estar consciente dos possíveis impactos que suas
decisões podem ter sobre estes grupos chave. (CANCELLIER, 2000, p. 1). Diante disso é que Cancellier (2000) ressalta, ainda, que essa análise dos stakeholders é importante em virtude de promover a adequada interpretação das mudanças no ambiente e de suas repercussões. "E nisso repousa o êxito da empresa, já que a administração das relações com os stakeholders é essencial no longo prazo para o bom funcionamento das organizações" (SENDER; FLECK, 2004 apud HOFFMANN; PROCOPIAK FILHO; ROSSETO, 2008, p. 22). 


\subsubsection{Importância da identificação dos stakeholders na implementação da estratégia}

Conforme mencionado no item anterior, a estratégia envolvida na identificação e análise dos stakeholders promove a adequada interpretação das mudanças do meio ambiente e suas repercussões (CANCELLIER, 2000). Nesse contexto, Ruas (2003, p. 7) propõe que é "essencial a identificação das necessidades e expectativas dos clientes com relação à organização, justamente para haver um alinhamento da estratégia de negócio".

Diante disso, Almeida, Fontes Filho e Martins (2000) ressaltam que tanto as empresas privadas quanto as públicas precisam continuamente de informações pertinentes dos stakeholders. A conseqüência disso é que a organização tem maiores possibilidades de responder aos seus interessados externos, se conhecer melhor os stakeholders (STARIK, 1995 apud HOFFMANN; PROCOPIAK FILHO; ROSSETO, 2008).

Oliver (1991 apud GOMES, 2005) ainda enfatiza essa questão, entendendo que, de um modo geral, a sobrevivência de uma organização relaciona-se com sua capacidade de gerenciar as influências dos stakeholders, a fim de evitar ameaças ou explorar as oportunidades.

\footnotetext{
Para que uma organização cumpra com efetividade sua missão, é imprescindível que suas ações decorram de um planejamento organizado e permanente, baseado nas políticas e diretrizes públicas às quais a organização se vincula, no conhecimento das expectativas de clientes e usuários, e levando em conta as condições e meios de que dispõe. (BRASIL, 1998, p. 14, grifo nosso).
}

Freitas (2010, p. 24) analisa que "o monitoramento do ambiente externo é levado em conta no processo de elaboração de estratégias, além da busca pelo atendimento aos vários stakeholders que influenciam e são influenciados pela organização".

Conforme analisado por Hoffmann, Procopiak Filho e Rosseto (2008), diversos estudos nacionais (GHISI, 2001; PINTO; OLIVEIRA, 2004; ROSSETTO, 1998; ABINO et al., 2005) e internacionais (CLARKE, 2005; FREEMAN; LIEDTKA, 1997; METCALFE,1998), apóiam o uso da teoria dos stakeholders na análise do ambiente organizacional, como ferramenta de estratégia.

A importância do ambiente nos estudos que buscam explicar a relação entre stakeholders e as organizações de determinado setor fica clara quando se depara com certas afirmações como as de Clarkson (1995), que escreve 
que o desempenho de uma organização traduzida por seus objetivos de negócio é mais bem desenvolvido quando se utiliza a perspectiva dos stakeholders (HOFFMANN; PROCOPIAK FILHO; ROSSETO, 2008, p. 23).

Cumpre esclarecer, entretanto, que o processo de gestão dos stakeholders envolve mais que sua identificação, mas também o grau de influência/interesse dessas partes na organização e quais estratégias que a empresa tem de empregar para gerir adequadamente suas relações (GOMES, 2005) na formulação da estratégia organizacional.

Pela peculiaridade no setor público, foi que o estudo de Gomes (2005), realizado em instituições governamentais inglesas no período de 2000 a 2003, ressaltou a relevância em se identificar a influência dos stakeholders em organizações públicas. Foi demonstrado que essas influências representam questões críticas para o processo de gestão estratégica nas organizações públicas e a conclusão foi que a teoria das partes interessadas "é uma questão importante para a elaboração de um planejamento estratégico no público e no privado, bem como para organizações lucrativas e não-lucrativas." (GOMES, 2005, p. 25, tradução nossa).

Diante disso, apesar das diferenças políticas, econômicas e culturais dos dois países, pode-se estabelecer uma estreita relação entre a identificação das necessidades do cidadão e os objetivos a serem agregados no Planejamento Estratégico, de modo que a prestação do serviço esteja sempre a contento.

\subsubsection{O cidadão como foco: novo paradigma da administração pública}

A Reforma Gerencial da Administração Pública, iniciada em 1995, consistiu na mudança da cultura burocrática e ao início de uma estratégia gerencial pública,

por meio da adoção de formas modernas de gestão no Estado brasileiro, que [possibilitou] atender de forma democrática e eficiente as demandas da sociedade. [Foi] uma reforma que, ao fazer uso melhor e mais eficiente dos recursos limitados disponíveis, [...] [tornou] viável uma garantia mais efetiva dos direitos sociais por parte do Estado. (BRESSER PEREIRA, 1998, p. 17).

O advento da Administração Pública Gerencial acarretou em diversas mudanças de paradigma no setor público brasileiro. Veio à tona não apenas a necessidade, mas a verdadeira importância de adoção de novas formas de administrar a máquina 
pública, com enfoque no atendimento ao cidadão e na adequada prestação de serviços públicos.

Entretanto, essa mudança de perspectiva envolve mudanças, sobretudo no aspecto cultural (COUTINHO, 2000 apud BARACHO, 2002), considerando a necessidade da implantação de uma cultura de prestação de serviços. Baracho (2002, p. 28) destaca que a Reforma do Estado parte da premissa de que a nova administração pública precisa estar "fundamentada em valores e crenças que enfatizem a importância do público, não como setor público, mas como um setor da economia e da sociedade que deva estar voltado para atender aos interesses do cidadão", provendo um padrão mínimo de qualidade.

O foco no cidadão e na sociedade representa o ponto em que o
compromisso com a excelência se torna um compromisso com o cidadão e
com a sociedade. As organizações públicas têm a obrigação de atender,
com presteza e qualidade, às demandas dos cidadãos usuários de seus
serviços A organização deve alinhar suas ações e seus resultados às
necessidades e expectativas dos cidadãos e da sociedade. Mais ainda:
deve antecipar tais necessidades. (ANDRADE JÚNIOR, 2009, p. 97).

Coutinho (2000 apud BARACHO, 2002, p. 29), corroborando ao exposto acima, destaca que a definição do cidadão como foco "é um dos principais pressupostos do modelo da administração pública gerencial”.

Complementando, Bresser Pereira (1998, p. 119, grifo nosso) faz a seguinte afirmação: "a idéia de que o cidadão deve ser visto como cidadão-cliente é central na Reforma Gerencial [...]. A orientação para o cliente, importada da administração de empresas, significa exatamente isso: atender às necessidades do cliente, respeitá-lo". Nesse sentido, defender o interesse público, oferecer à sociedade um serviço público de qualidade e atender às necessidades dos cidadãos devem ser as metas prioritárias a serem perseguidas. 


\section{MÉTODOS E TÉCNICAS DE PESQUISA}

Este capítulo descreve a metodologia utilizada na pesquisa para alcançar o objetivo proposto e demonstrar como o problema central foi solucionado. Diante disso, são expostos o tipo e a descrição geral da pesquisa; a caracterização da organização; os participantes do estudo; os instrumentos de pesquisa; e os procedimentos de coleta e de análise de dados.

\subsection{Tipo e descrição geral da pesquisa}

O tipo da pesquisa realizada é classificado como de natureza qualitativa. Segundo Neves (1996, p. 1), a pesquisa qualitativa "compreende um conjunto de diferentes técnicas interpretativas que visam a descrever e a decodificar os componentes de um sistema complexo de significados". Considerando essa análise de situações complexas ou estritamente particulares, Richardson (1999) complementa que a abordagem qualitativa torna-se o método apropriado para compreensão de um fenômeno social.

Menezes e Silva (2000) destacam que, nesse tipo de pesquisa, a análise dos dados tende a ocorrer de maneira indutiva e não há exigência da utilização de métodos e técnicas estatísticas. Diante disso, o presente estudo utilizou a metodologia de entrevistas semi-estruturadas para coleta de dados.

A classificação da pesquisa teve como base a taxonomia apresentada por Vergara (2007): quanto aos fins e quanto aos meios.

Quanto aos fins, a pesquisa classifica-se como descritiva, que é a exposição das "características de determinada população ou de determinado fenômeno" (VERGARA, 2007, p. 47), procurando descrever os fatos observados.

Quanto aos meios, a investigação foi pesquisa de campo, com a estratégia no estudo de caso, sendo o último embasado por meio de coleta de dados secundários: bibliográfica e documental. 
A pesquisa de campo é a "investigação empírica realizada no local onde ocorre ou ocorreu um fenômeno ou que dispõe de elementos para explicá-lo" (VERGARA, 2007, p. 47), podendo ser realizada por meio de entrevistas, questionários ou testes. Marconi e Lakatos (2002) destacam que a pesquisa de campo é uma fase subseqüente ao estudo bibliográfico, considerando a importância do pesquisador obter um bom conhecimento sobre o assunto antes de realizar a investigação.

O estudo de caso, segundo Neves (1996), consiste na análise profunda e detalhada de uma unidade de estudo, buscando saber como e por que ocorrem determinados fenômenos dentro de um contexto específico.

A pesquisa bibliográfica é o "estudo sistematizado desenvolvido com base em material publicado em livros, revistas, jornais, redes eletrônicas, isto é, material acessível ao público em geral." (VERGARA, 2007, p. 48).

Por fim, a análise documental, de acordo com Vergara (2007), é a investigação de documentos de qualquer natureza de órgãos públicos e privados. Neves (1996) complementa que pode oferecer uma base útil de informações para outros tipos de pesquisa qualitativa.

\subsection{Caracterização da organização, setor ou área}

O Tribunal de Justiça, com sede no Distrito Federal, compõe-se de 35 desembargadores, 166 juízes titulares, 115 juízes substitutos e cerca de 5.900 servidores e exerce sua jurisdição no Distrito Federal e nos Territórios, conforme disciplina a Lei de Organização Judiciária do Distrito Federal.

A justiça de Primeiro Grau encontra-se à disposição da população em várias Regiões Administrativas do Distrito Federal, totalizando quatorze Circunscrições Judiciárias, conforme Lei no 11.697, de 13 de junho de 2008.

O Tribunal conta, atualmente, com 255 órgãos instalados (Varas e Juizados), sendo 208 Varas Comuns e 24 Juizados Especiais de Justiça de Primeira Instância e 23 Varas de Violência Doméstica e Familiar Contra Mulher, subordinados ao Corregedor da Justiça do Distrito Federal, a quem compete supervisionar os serviços 
forenses e coordenar projetos que visem à melhoria da qualidade dos serviços jurisdicionais prestados à população.

Encontra-se, ainda, na estrutura do Tribunal, a área administrativa para dar suporte à atividade-fim da Instituição e viabilizar o funcionamento adequado dos órgãos judiciais. Toda essa estrutura está à disposição para atender aos litígios da sociedade e garantir o direito do cidadão. A organização judiciária do TJDFT tem o objetivo de ampliar e adequar sua estrutura aos anseios da sociedade, de modo a atendê-la com eficácia e rapidez.

\subsection{Participantes do estudo}

Considera-se que o objetivo do estudo é descrever a implementação do Planejamento Estratégico no TJDFT, com análise dos atores envolvidos na sua consolidação. Diante disso, a escolha dos participantes do estudo foi definida por meio dos níveis de planejamento (estratégico, tático e operacional), de forma a identificar as percepções e as perspectivas diferenciadas de cada nível no âmbito organizacional sobre a implementação do Planejamento Estratégico e seu impacto na prestação jurisdicional.

Os perfis dos participantes são assim detalhados:

a) 01 (um) integrante do nível estratégico (alta administração): desembargador Lécio Resende, que estava na Presidência do TJDFT quando da implantação do Planejamento Estratégico no TJDFT em 2007;

b) 03 (três) integrantes do nível tático (área meio):

- Entrevistado A: servidor do TJDFT há 12 anos. Técnico Administrativo. Envolvido diretamente no processo de adoção e implementação do Planejamento Estratégico, por atuar na área de Planejamento à época;

- Entrevistado B: servidora do TJDFT há 16 anos. Técnica Administrativa. Atua na área de Recursos Humanos e, à época, era Substituta do Serviço de Capacitação e Desenvolvimento, setor que, em detrimento de pesquisas internas, fomentou a necessidade do Planejamento Estratégico no órgão; e 
- Entrevistado C: servidora do TJDFT há 03 anos. Analista Administrativa - Área Estatística. Atualmente, encontra-se no setor de Planejamento Estratégico e trabalha com indicadores de desempenho.

c) 01 (um) integrante do nível operacional (área fim):

- Entrevistado D: servidora do TJDFT há 16 anos. Analista Judiciário. Por trabalhar na área fim, possui a visão do nível operacional com a implementação do Planejamento Estratégico.

\subsection{Caracterização dos instrumentos de pesquisa}

O estudo de caso consistiu, primeiramente, na coleta e na análise de dados secundários, sendo verificada tanto a bibliografia referente ao Planejamento Estratégico no Poder Judiciário (presente em periódicos científicos nacionais e internacionais, em dissertações, em livros, revistas, dentre outros), quanto em documentos em poder da organização (dados oficiais e não oficiais, relatórios, planilhas e documentos que mostrem a evolução do Planejamento Estratégico).

Com o intuito de alcançar os objetivos propostos, foi realizada pesquisa de campo junto aos atores envolvidos no processo de implementação do Planejamento Estratégico no TJDFT. Eles foram identificados por meio da relevância de suas atuações nos níveis organizacionais: estratégico, tático e operacional.

A coleta e de análise de dados primários consistiu em entrevistas semi-estruturadas, contemplando perguntas abertas elaboradas pela autora (APÊNDICE A), tendo como base o roteiro de entrevista elaborado por Alexandre J. Baracho em 2002. As entrevistas ocorreram com os integrantes dos níveis tático e operacional, e o uso do roteiro semi-estruturado deveu-se à peculiaridade de cada indivíduo no processo de Planejamento Estratégico.

O integrante de nível estratégico, pela indisponibilidade de tempo, não pôde ser entrevistado diretamente. Contudo, foram analisados os discursos do Desembargador Lécio Resende no início e no final de sua Gestão (2006-2008), que contribuem para verificar sua percepção diante do Planejamento Estratégico. 


\subsection{Procedimentos de coleta e de análise de dados}

A coleta dos dados se deu por meio de três procedimentos: análise bibliográfica, documental e entrevistas semi-estruturadas.

A análise bibliográfica consistiu em pesquisas e trabalhos relevantes sobre o tema de Planejamento Estratégico no Judiciário. Já a análise documental, foi realizada por meio do exame de documentos do TJDFT, sobretudo do PLABI - Plano de Gestão do Biênio (elaborado no início da gestão do Presidente) e do RELBI - Relatório de Atividades e Resultados do Biênio (elaborado no final da gestão do Presidente), que apontam a evolução do Planejamento Estratégico no órgão, sendo possível a extração de dados relevantes para a pesquisa.

As entrevistas semi-estruturadas tiveram como foco a obtenção de informações relevantes que apontem a situação do TJDFT antes e depois da implementação do Planejamento Estratégico e como foi promovido esse processo de construção, diante de diversas perspectivas. Foram realizadas de maneira presencial pela autora, no período de 15 a 17 de dezembro de 2010, no Fórum de Brasília Desembargador Milton Sebastião Barbosa.

Todas as entrevistas foram inteiramente gravadas e, posteriormente, foram transcritas para que houvesse a seleção dos trechos mais relevantes para elaborar o trabalho.

De acordo com a natureza do presente estudo e dos objetivos a serem alcançados, os dados serão analisados mediante o conteúdo, que, segundo Martins e Lintz (2009, p. 47), é a busca de "interferências confiáveis de dados e informações com respeito a determinado contexto, a partir dos discursos escritos ou orais de seus atores".

Bardin (1994, apud MARTINS; LINTZ, 2009, p. 47) descreve a análise de conteúdo como

um conjunto de instrumentos metodológicos cada vez mais sutis em constante aperfeiçoamento, que se aplicam a discursos (conteúdos e continentes) extremamente diversificados. $O$ fator comum destas técnicas múltiplas e multiplicadas - desde o cálculo de freqüências que fornece dados cifrados, até a extração de estruturas traduzíveis em modelos - é uma hermenêutica controlada, baseada na dedução: a inferência. Enquanto 
esforço de interpretação, a análise de conteúdo oscila entre os dois pólos do rigor da objetividade e da fecundidade da subjetividade.

Diante disso, a investigação procurou analisar o conteúdo das informações escritas e orais, para que fosse possível estabelecer parâmetros de mensurar o real impacto do planejamento estratégico na prestação dos serviços prestados pelo Tribunal. 


\section{RESULTADOS E DISCUSSÃO}

Neste capítulo, procura-se fazer a análise das entrevistas realizadas com os participantes sobre a experiência da implementação do Planejamento Estratégico, bem como da documentação coletada sobre o assunto, tomando por base a opção metodológica adotada para a realização da pesquisa. Desse modo, as entrevistas e os dados de fontes secundárias foram interpretados levando-se em conta os temas principais e secundários abordados na entrevista.

As seções estão relacionadas às principais perspectivas dos entrevistados sobre cada um dos seguintes temas: processo de implementação do Planejamento Estratégico; grau de conhecimento sobre o Planejamento Estratégico e seus impactos; atuação do Conselho Nacional de Justiça; as principais realizações com o uso do Planejamento Estratégico; e nível de satisfação do usuário.

\subsection{Processo de implementação do Planejamento Estratégico}

Esse item busca contextualizar o processo de implementação do Planejamento Estratégico no Tribunal de Justiça do Distrito Federal e dos Territórios, apontando, juntamente, os principais aspectos facilitadores e os dificultadores durante essa fase.

O processo de Planejamento Estratégico no Tribunal foi provocado a partir de um programa da área de Recursos Humanos, denominado Programa de Desenvolvimento Gerencial - PDG, no ano de 2006. O Programa tinha como uma de suas atividades, encontros periódicos com gestores onde se discutia pontos fortes e fracos na gestão do Tribunal. A descontinuidade de iniciativas, provocada pela mudança de gestão a cada dois anos, e a falta de Planejamento Estratégico foram reclames de praticamente todos os setores da Casa. Com isso, foi proposto o lançamento dessa idéia à administração do Tribunal que tomou posse em 2006. Inicialmente a ideia não foi acatada em virtude da crença de que causaria grande mudança cultural. Contudo, no final de 2006, devido ao empenho e comprometimento da equipe técnica responsável pela área de planejamento, 
programas e projetos, houve a contratação de uma empresa de consultoria, especializada e com grande conhecimento na área de gestão pública, para o desenvolvimento do Planejamento Estratégico do TJDFT.

O processo de elaboração do Plano "promoveu o envolvimento de representantes de todos os níveis de sua estrutura organizacional”. (RELBI, 2008, p. 74).

A proposta foi muito bem aceita porque não foi imposta de cima para baixo. Convidamos a Casa a conhecer os benefícios de se ter um Planejamento Estratégico (...) e convocamos todos para construir esse Plano. (...). As pessoas se sentiram parte do processo, puderam opinar e perceberam as vantagens. Foi muito positivo porque as áreas passaram a se conhecer, passaram a se falar. Coisa que não acontecia (ENTREVISTADO B).

Para compor as declarações de Missão e Visão do TJDFT, houve a participação de magistrados e servidores dos diferentes níveis organizacionais da Casa, os quais também auxiliaram na análise de contexto e de cenário, bem como na identificação dos Objetivos Estratégicos Institucionais. Cada um dos Objetivos Estratégicos foi vinculado a prazos, metas e indicadores correspondentes, que permitiram o acompanhamento da evolução da instituição rumo aos Objetivos Estratégicos traçados, "promovendo o processo contínuo de avaliação, insumo essencial para o aprimoramento da prestação de seus serviços à sociedade" (RELBI, 2008, p. 23).

Esse processo foi construtivo. Convidamos pessoas que pertenciam aos níveis estratégico, tático e operacional a participarem. Foi elaborada, primeiramente, uma análise SWOT do Tribunal. Juntos fizemos essa análise e construímos os valores, a missão, os objetivos estratégicos, depois foram formuladas ações que contribuíam com o alcance dos objetivos estratégicos (ENTREVISTADO B).

A integração entre a equipe técnica e os servidores de modo geral, o emprego de ferramentas e metodologias modernas e comprovadamente eficientes, e o apoio da alta administração foram fatores bastante positivos (ENTREVISTADO A).

Apesar de muitos aspectos facilitadores exemplificados, como o patrocínio da alta administração, foram citados pelos entrevistados alguns obstáculos encontrados durante o processo de elaboração do Plano.

O principal obstáculo foi a crença de que aquilo era um modismo e que não ia dar certo, que era perda de tempo. Então, o fato de não conhecer e já criar um "pré-conceito", pra mim, eu imagino que seja um dos principais obstáculos (ENTREVISTADO B). 
No meu entendimento, a aplicação do BSC no processo de elaboração do Plano Estratégico do Tribunal deixou muito a desejar em vários aspectos, principalmente no que se refere à participação dos diretamente interessados. Um grupo muito pequeno de colaboradores foram ouvidos no processo de levantamento de informações. A participação de um maior número de servidores na construção do Plano, principalmente os do nível operacional, enriqueceria sobremaneira o produto final (ENTREVISTADO A).

A interferência de questões políticas em detrimento ao conhecimento técnico, durante o processo de implementação, prejudicou a qualidade e a confiabilidade do produto final. É, sem dúvida, o fator que mais prejudica sua consolidação, os impactos dessa interferência são sofridos durante todo o tempo de vigência do plano (ENTREVISTADO A).

Em 23 de abril de 2007, por meio da Portaria nำ 14, a empresa de consultoria contratada, juntamente com os técnicos dos TJDFT, entregou o produto do seu primeiro ciclo de planejamento estratégico.

Ao tomar posse no cargo de Presidente desta augusta Corte de Justiça, exprimi a preocupação em concentrar as atividades jurisdicionais e administrativas, bem como implementar a elaboração de uma metodologia de trabalho que permitisse a concretização dos serviços, acompanhado da avaliação das etapas de implantação. Para tanto, o Tribunal de Justiça do Distrito Federal e dos Territórios instituiu o Plano Estratégico, por meio da Portaria Conjunta no 14, de 23 de abril de 2007, e passou a compor o rol das Instituições Públicas que investem em metodologias e técnicas específicas para a composição e o acompanhamento do planejamento, gerando, desta forma, soluções de questões institucionais com agilidade, economia e eficácia. As práticas de planejamento, acompanhamento e controle implantadas nesta Gestão permitiram o efetivo registro dessa evolução, que se configura como importante legado a ser oferecido aos próximos dirigentes dessa Casa (DESEMBARGADOR PRESIDENTE LÉCIO RESENDE).

\subsection{Grau de conhecimento sobre Planejamento Estratégico e os impactos sentidos pelos servidores}

A análise desse item procurou compreender, de acordo com as perspectivas dos entrevistados, o grau de conhecimento dos servidores sobre o Planejamento Estratégico e avaliar os impactos de sua implementação no Tribunal de Justiça do Distrito Federal e dos Territórios.

Porto e Belfort (2001) e Barreto e Dostler (2009) destacam que o grande propósito em se definir a visão de futuro para a organização é o de criar uma imagem que inspire, desafie e mobilize todas as pessoas envolvidas no âmbito organizacional. 
Diante disso, o grau de conhecimento dos colaboradores do TJDFT impulsiona a organização como um todo na efetivação do Planejamento Estratégico.

Nesse sentido, vale destacar alguns trechos dos participantes da área meio referentes a esses assuntos:

No Tribunal, o que acontecia: a cada dois anos, com a mudança da gestão, havia projetos e ações que estavam em andamento, e simplesmente eram abandonados, literalmente, porque não eram de interesse da nova administração. Mais ou menos como acontece no executivo, o novo governante chega, não interessa o que o governante anterior fez, engaveta tudo, dispensa tudo e vamos propor coisa nova (...). Não havia uma continuidade, nós não tínhamos um norte. A Casa não tinha um norte (ENTREVISTADO B).

O que tinha antes eram relatórios, que eram cobrados no final do ano, no apagar das luzes, não havia embasamento nenhum. Não tinha um ponto de partida e um ponto de chegada para se comparar e ver se realmente houve uma evolução positiva ou não (...). Nós ficávamos perdidos (ENTREVISTADO B).

O Tribunal de Justiça sempre esteve na vanguarda na utilização de técnicas e ferramentas de gestão, porém, antes de 2007, a prática da gestão pública dependia mais da intuição dos gestores do que das técnicas e ferramentas disponíveis (ENTREVISTADO A).

A meu ver a mudança mais significativa e impactante foi a clareza na definição do foco a ser seguido (ENTREVISTADO A).

Antigamente, a gente trabalhava somente com a atividade de fazer a prestação jurisdicional. Hoje em dia, eu vejo que tem uma organização interna administrativa muito mais forte (ENTREVISTADO B).

O que se percebe é que os entrevistados da área meio sentiram fortemente 0 impacto do Planejamento Estratégico. Anteriormente ao ano de 2007, o TJDFT não possuía visão de futuro que guiasse os colaboradores para uma melhor prestação jurisdicional. Além disso, com a mudança de gestão, ocorrida a cada dois anos, ações e projetos iniciados em outra gestão corriam risco de serem descontinuados. Contudo, o entrevistado da área fim não percebeu de forma tão profunda essas mudanças:

A influência desse planejamento de forma direta não é muito perceptível para as pessoas da área judiciária. $O$ jeito de atender não teve uma modificação muito grande. Essa questão não vem de uma forma clara. Ela vem de uma forma natural, quase implícita. Mas de forma clara, não. Ninguém sabe o que se faz na área administrativa a ponto de isso fazer uma diferença na nossa atuação aqui. Agora, levando em consideração que nós temos recursos materiais, uma possibilidade de execução dessas 
tarefas de forma mais simplificada, desse apoio que o tribunal dá, aí sim é possível perceber. A própria estrutura física, as varas hoje possuem estante pra guardar os processos, não falta mais material, tem havido mudanças no mobiliário. Então, vão vir mudanças que eu acho que faz parte de um planejamento anterior e que, a gente que está aqui na ponta não percebe. $\mathrm{E}$ que isso vem acontecendo aos pouquinhos, atingindo o servidor $e$, conseqüentemente, o atendimento (ENTREVISTADO D).

Os pronunciamentos dos entrevistados da área meio corroboraram esta lacuna existente: pouco conhecimento do Planejamento Estratégico pela área fim.

Na verdade, o que a gente tem percebido é que o TJDFT, aos poucos, vai tendo noção do que é o Planejamento Estratégico. Não são todos na Casa hoje que tem conhecimento dele em toda a sua essência e amplitude. Mas ele está acontecendo, aos poucos. A área administrativa tem mais contato. (ENTREVISTADO B).

A meu ver, esse ainda é um ponto fraco do Planejamento Estratégico no Tribunal. Ele está bastante difundido em algumas unidades da área administrativa, geralmente aquelas unidades que estão diretamente envolvidas com sua implementação, e na área judicial ele não é conhecido ou compreendido em quase todas as unidades. (ENTREVISTADO A).

Eu acho que falta divulgação, melhorou, mas ainda tem muito a melhorar. Eu poderia dizer que de 2006 pra cá nós já atingimos 60\%. Então precisa melhorar (ENTREVISTADO B).

De forma a subsidiar essa análise, verificou-se, no relatório de avaliação do nível de conhecimento do Planejamento Estratégico do biênio 2008-2010 do TJDFT, que apenas $41 \%$ dos entrevistados, entre magistrados e servidores, possuíam conhecimento simultâneo acerca da Missão, Visão e Objetivos Estratégicos da Casa. Isso revela que a divulgação interna ainda mostra-se insuficiente para a maioria dos colaboradores.

Esses apontamentos remetem ao posicionamento de Oliveira (2006), ao explicar que o planejamento estratégico deve ser visto como um instrumento capaz de ajudar a empresa a se conhecer e a ter uma visão de futuro.

Todos os entrevistados da área meio, inclusive, ao serem questionados sobre os fatores determinantes para a consolidação do Planejamento Estratégico no TJDFT, apontaram a divulgação como sendo primordial:

A primeira coisa é a divulgação. Penso que a divulgação é uma peça fundamental dentro do Planejamento Estratégico, tanto internamente quanto externamente. Tem que divulgar. Hoje, inclusive, nós temos uma divulgação melhor. A nossa Assessoria de Comunicação Social conseguiu fazer essa ponte. Ou seja, em relação à sociedade, acredito que ela conhece melhor o 
tribunal. Mas precisamos melhorar ainda mais nesse aspecto. Utilizamos ferramentas modernas, pra se ter uma idéia estamos no Twitter, temos hotsites bem interessantes para auxiliar com a divulgação de projetos. Mas ainda precisamos fazer uma divulgação mais próxima de quem está na ponta, àquela pessoa que está lá no cartório, que atende no balcão. Não é toda hora que ele pode entrar na intranet ou no e-mail. É complicado, às vezes. Divulgação é importantíssimo (ENTREVISTADO B).

Em primeiro lugar, a divulgação. Divulgar as melhorias também, pra justamente mostrar às pessoas que o que foi planejado deu resultado. Às vezes, no atendimento, o jurisdicionado está mais satisfeito, mas ele não sabe 0 que foi feito, o porquê melhorou. Ele não sabe que houve um planejamento e uma ação que provocou essa melhoria. Que aquilo pertencia a um objetivo estratégico de melhoria. Ele até percebe que melhorou, mas não enxerga o que está por trás (ENTREVISTADO C).

Um plano de comunicação melhor estruturado e executado contribuiria muito com o resultado e com a participação de toda a Casa nesse movimento (ENTREVISTADO A).

A divulgação é, de fato, item essencial para concretização do Planejamento Estratégico no TJDFT. Contudo, diante do seguinte posicionamento do entrevistado da área fim, percebe-se que a forma como está sendo conduzida a divulgação no Tribunal mostra-se ineficaz para quem trabalha no atendimento:

Eu acho a divulgação interessante. Eu, pessoalmente, acompanho algumas coisas. No nosso dia-a-dia, a gente nem precisa olhar essas coisas para poder trabalhar, porque, sinceramente, tem gente que não pára para olhar email, o volume de trabalho aqui é muito grande. Então, se tem tempo de olhar alguma coisa, a pessoa vai olhar outra coisa que não seja ver o que estão planejando para o Tribunal. Teve uma época que eu não dava a menor importância para aquele cartaz do planejamento. O tribunal mandou a gente colocar, a gente colocou. Mas ninguém pára pra olhar e entender 0 que é aquilo. Nem tentar entender (ENTREVISTADO D).

\subsection{Atuação do Conselho Nacional de Justiça}

O tópico possui o objetivo de assinalar as perspectivas dos entrevistados diante da atuação do Conselho Nacional de Justiça no processo de Planejamento Estratégico.

O Conselho Nacional de Justiça, órgão de controle administrativo e financeiro do Poder Judiciário, instituiu, por meio da Resolução n. 70, o Planejamento Estratégico do Judiciário e determinou, dentre as 10 Metas de Nivelamento, que todas as instituições desse Poder deveriam desenvolver e/ou alinhar seus respectivos 
Planejamentos Estratégicos ao Planejamento Nacional, com duração mínima de cinco anos, a partir de 2010.

A conseqüência disso, sem dúvidas, foi proporcionar a integração do Judiciário brasileiro, de forma que todos os Tribunais ficassem nivelados e alinhados.

A interação entre os Tribunais é muito importante. Aí entra um dos objetivos do CNJ em promover essa integração, de que não é cada um por si (ENTREVISTADO B).

Esse alinhamento é extremamente positivo, uma vez que possibilita aos tribunais de todo país falarem a mesma língua no que se refere à gestão pública. Possibilitará, também, ganhos indiretos a logo prazo que terão impactos ainda maiores. No meu entendimento, penso que em um futuro próximo todos os tribunais estarão falando a mesma língua também em outras áreas, como a TI. Não existem motivos para cada tribunal utilizar sistemas de automação diferenciados, o desperdício de recursos públicos causado por essa desintegração é incalculável (ENTREVISTADO A).

Sem o CNJ, não haveria movimentação nenhuma nesse sentido de planejamento estratégico. Então o CNJ obriga a gente a começar a pensar nessas coisas (ENTREVISTADO C).

O servidor da ponta no cartório começa a entender o porquê de algumas metas serem colocadas pelo $\mathrm{CNJ}$, dentro do planejamento estratégico do judiciário, que são cobradas da instituição. Tem que dar resposta. E então, quando o Tribunal está estruturado também com o mesmo modelo de planejamento estratégico e que tem metas internas pra poder alcançar seus objetivos e responder essas metas do planejamento do judiciário, é como se estivesse no micro e fosse para o macro (ENTREVISTADO B).

Percebe-se que o CNJ possui grande empenho no desenvolvimento de suas atividades na "busca incessante da melhoria da gestão administrativa, com a diminuição dos custos e a maximização da eficácia dos recursos" (MENDES, 2009, p. 4), procurando aperfeiçoar a prestação jurisdicional brasileira.

Vale ressaltar, ainda, que o Conselho, por meio de Encontros Anuais entre o Judiciário Nacional, promove trocas de experiências que agregam valor entre todos os Tribunais, como concorda um dos entrevistados:

O CNJ obrigou as instituições a conversarem entre si. (...). Então a própria Justiça Trabalhista, que era totalmente distante da Justiça Comum, passou a conversar com a gente e a gente com eles. (...). Começa a haver buscas de experiências que deram certo em outras instituições e que pode servir para nós. $E$ aquilo que não deu certo também é interessante, porque já sabemos que não vamos promover dessa maneira, vamos promover de outra. O que acontece hoje é que se tem um CNJ cobrando de várias instituições do judiciário que se tenha planejamento estratégico e que todos conversem entre si (ENTREVISTADO B). 
Segundo Relatório Consolidado do CNJ, tanto as 10 Metas de Nivelamento quanto as 10 Metas Prioritárias movimentaram os órgãos do Poder Judiciário rumo ao aprimoramento e à modernização de suas sistemáticas de trabalho, impactando em melhorias substanciais na prestação dos serviços à sociedade. O TJDFT cumpriu mais de $90 \%$ das Metas de Nivelamento estabelecidas pelo CNJ para o ano de 2009: das dez metas, oito foram cumpridas integralmente e duas parcialmente (a Meta 2 e a Meta 8). As Metas Prioritárias foram cumpridas quase em toda sua totalidade, restando apenas a Meta 1, a Meta 2 e a Meta 4.

Foram apontados pelos stakeholders, contudo, que as cobranças do CNJ se mostram, muitas vezes, como algo negativo:

O CNJ se atropela, ele cobra além do que ele consegue processar, além de cobrar besteiras. Então nesse sentido, eles são falhos (ENTREVISTADO C).

Eu acho que às vezes as cobranças são feitas de forma enviesada. Têm-se pesos e medidas iguais para realidades diferentes, para órgãos diferentes (ENTREVISTADO B).

Essa cobrança do $\mathrm{CNJ}$, segundo um dos entrevistados, prejudica, muitas vezes, a prestação jurisdicional, em virtude do atendimento dessas demandas. A principal conclusão que se pode extrair das exigências do CNJ é ressaltada pelo entrevistado da área fim:

Digamos que o $\mathrm{CNJ}$ precise de alguns dados que o nosso sistema não dispõe de condições pra fornecer imediatamente e que aquilo tem que ser desenvolvido. Por que o CNJ não cria um sistema unificado? Ele podia criar um sistema unificado pra todos os tribunais, claro, levando em consideração a competência de cada um (justiça do trabalho, justiça federal, justiça comum).

Criava um sistema de justiça e, aos poucos, os tribunais iam migrando pra aquele sistema. (...). E eles aprimorariam, eles coletariam esses dados diretamente da base deles, (...) e deixariam a gente fazer o nosso serviço, que é a parte jurisdicional. $\mathrm{E}$ eles com a área técnica e com a área administrativa coletariam esses dados. Então não precisava pedir pra gente, ele vai lá e pega na base de cada tribunal.

Tem dados que o tribunal precisa repassar para o $\mathrm{CNJ}$ e que a gente não tem na nossa base. Então, vai ter que desenvolver aquela informação, tentar coletar e depois tentar enviar para o CNJ. E tem dados que não são possíveis de coletar dentro do sistema atual do tribunal. Então, se o CNJ desenvolvesse esse sistema, que se amoldaria às necessidades deles, mas também permitiria que a gente exercesse nosso trabalho, como naturalmente a gente já faz, esses dados poderiam ir direto pra base deles. Facilitaria dos dois lados. 
E eu não conheço os sistemas de outros tribunais, mas digamos que um Tribunal tenha um sistema pior que o nosso, vai passar por mais dificuldades para fornecer esses dados. E tem tribunal que tem um sistema melhor, então esse tribunal vai ter facilidade de informar os dados. E por esse critério, o CNJ classifica cada tribunal. Então,um tribunal ruim é um tribunal que não tem como fornecer os dados. Mas será que esses dados, por ausência de fornecimento, geram um mau atendimento à população? Então, essas coisas que eu questiono nos dados do CNJ, mas eu acho que o CNJ, um dia, vai conseguir avaliar todos os tribunais com critério isento. Por enquanto, eu ainda acho que depende das condições de cada tribunal. Porque se qualquer tribunal deixa de passar um dado significa que aquele tribunal não produz aquele dado ou não produz a tarefa que resulta naquele dado. Enquanto não desenvolve a solução para aquele dado, a situação que se fica é a de que, na interpretação do CNJ, o tribunal não tem, não faz, ou não tem condições. A interpretação imediata é ruim. Então seria importante que ele desenvolvesse algo que todos pudessem ser avaliados de forma igual (ENTREVISTADO D).

\subsection{Principais realizações}

Esse item aborda as principais realizações e melhorias no TJDFT, após a implementação do Planejamento Estratégico.

As coisas não são propostas mais de maneira solta e aleatória. Elas são propostas dentro de um alinhamento com a estratégia da Casa (ENTREVISTADO B).

Essa afirmação denota que, atualmente, as ações desenvolvidas no âmbito do TJDFT estão alinhadas com a estratégia da Casa, devido ao estabelecimento de um Planejamento Estratégico.

\subsubsection{Capacitação de funcionários e otimização de recursos}

\section{O Planejamento Estratégico do TJDFT utilizou a metodologia do Balanced}

Scorecard, diante disso percebe-se que um grande ganho foi,

por exemplo, ter um objetivo estratégico que é "estabelecer e implantar políticas de capacitação com foco em competências". Está totalmente alinhado com a estratégia da Casa. Então para se ter essas ações de capacitação e desenvolvimento, com base em competências, deve-se conhecer quais são as competências necessárias para a Casa atingir os seus objetivos estratégicos. Pra isso, deve entender, também, quais são as competências que o servidor tem atualmente. E se ele não tem, deve fazer o que? Desenvolver. Mas não vamos desenvolver qualquer coisa. Não 
vamos trazer qualquer curso de capacitação e desenvolvimento para a Casa. Vamos trazer aquela ação de capacitação e desenvolvimento que aquele servidor precisa pra atender àquela competência que a Casa necessita e que vai contribuir para atingir o objetivo estratégico. $E$ então, começa a alinhar isso (...). A área de Recursos Humanos deve entender como fazer esse levantamento dessas competências dos servidores de acordo com as competências necessárias pra Casa, apontar para área de capacitação e desenvolvimento pra que ela traga ações de capacitação e desenvolvimento adequado e possa otimizar, inclusive, recursos (ENTREVISTADO B).

Essa declaração confirma a explicação de Ruas (2003) sobre a perspectiva financeira do BSC. No poder público, é vista como um fator restritivo, devido ao orçamento fixo, devendo, portanto, enfatizar os aspectos que forneçam maior eficiência na gestão de custos, mas que agreguem, também, o máximo de valor para a sociedade. Portanto, desenvolver ações de capacitação adequadas às necessidades do TJDFT promoveriam não apenas o alinhamento organizacional, que é de suma importância, mas garantiriam a otimização de recursos.

\subsubsection{Integração entre as unidades organizacionais}

Um dos grandes aspectos positivos do uso do Planejamento Estratégico, utilizando a metodologia do BSC, é justamente o correlacionamento das ações entre si numa cadeia de causa e efeito, considerando as quatro perspectivas, de modo a identificálas no alcance de cada objetivo estratégico (RUAS, 2003). A conseqüência disso é que as unidades organizacionais passam a ser mais entrelaçadas e a desenvolver atividades conjuntamente.

Um dos maiores ganhos que eu vejo foi o fato das secretarias passarem a se conhecer, passarem a trabalhar juntas. Entender onde estavam as interfaces entre uma secretaria e outra. E então trabalharem, vislumbrando possibilidades de parcerias (...). Eu percebo que isso é positivo porque a área administrativa apóia a área fim. Começamos a ter um contato maior também com a área fim. Começou a ser interessante esse movimento. Começou a se perceber que todos estavam na mesma instituição (...). É como se fosse uma grande corrente, cada elo é muito importante (ENTREVISTADO B). 


\subsubsection{Continuidade das ações}

A continuidade das ações, em qualquer âmbito político, é sempre um ponto fraco observado. Muitas vezes, conflitos de interesse entre os Desembargadores e até mesmo certa 'vaidade', implicam em encerramentos de projetos e em descontinuidades administrativas.

A outra coisa bacana foi que passa a ter uma continuidade. Então, os projetos que acontecem na casa e no próprio poder judiciário têm uma continuidade, se estiverem alinhados com a estratégia da Casa (ENTREVISTADO B).

Foi mudança drástica porque a gente conseguiu manter projetos na Casa, ações na casa, mudando de uma gestão para outra, dando continuidade (ENTREVISTADO B).

Outro aspecto importante é que projetos não são mais abandonados no meio da execução por causa de mudanças na cadeia de comando (ENTREVISTADO A).

Observa-se que os entrevistados ressaltam a importância de ter havido continuidade na Casa com o desenvolvimento de projetos e ações continuadas. $O$ índice de realização do último Plano do Biênio $2008-2010$ foi de $56 \%$ no alcance das metas e no cumprimento dos objetivos.

O índice foi bastante satisfatório, principalmente pelo fato de ter reduzido quase a zero o problema da descontinuidade das ações, causado por mudanças de gestão (ENTREVISTADO A).

Além disso, segundo o entrevistado $B$, a continuidade de ações e a consolidação do Planejamento Estratégico se deveram, também, em função da transição 'amigável' entre a gestão que encerrou em 2008 e a que entrou em 2008:

Teve todo um lado político e de vaidade na história. Para um desembargador era "o senhor vai encerrar sua gestão trazendo o Planejamento Estratégico para Casa". Para o outro era "o senhor vai iniciar a sua gestão com o Planejamento Estratégico". Então, tanto a metodologia que foi utilizada, a de construção do Planejamento Estratégico com os gestores (estratégicos, táticos e operacionais), quanto a negociação política entre os dois dirigentes da Casa foram muito importantes. Por isso, também, ela foi muito bem aceita (ENTREVISTADO B). 


\subsubsection{Ações relevantes e infraestrutura}

Muitas ações de relevância contribuíram para melhorar os serviços prestados aos jurisdicionados do TJDFT. Dentre os projetos, pode-se citar: o Projeto de Divulgação do Programa Viver Direito, de responsabilidade socioambiental; a Pesquisa de Clima Organizacional; a construção do Fórum José Júlio Leal Fagundes, do Fórum de São Sebastião e da reforma do Bloco A do Fórum de Brasília; o Projeto de Redução no Orçamento de Material de Consumo; a implantação do Instituto Ministro Luiz Vicente Cernicchiaro, de capacitação e desenvolvimento; a construção das cabines do Protocolo Expresso, etc.

Ter construído isso tudo ajudou no atendimento à população porque está mais próximo do usuário de modo geral (ENTREVISTADO D).

Com o Programa Viver Direito, eu pude perceber algo bem forte nessa questão da economia, que todo mundo ficou com a visão de aproveitar papel. Esse tipo de coisa que a gente fazia de uma forma natural, porém não obrigatória, passou a ser mais intensa porque se tornou obrigatória, uma meta que o tribunal precisa atingir (ENTREVISTADO D).

Além dessas obras, foi determinada, ainda, a elaboração dos projetos para a construção do Fórum do Guará e autorizado o início dos processos de licitação de uma nova unidade para abrigar somente as Varas de Família, no Complexo Desembargador José Júlio Leal Fagundes.

Por fim, destacam-se também a sanção da nova Lei de Organização Judiciária do Distrito Federal e Territórios (lei no 11.697), em junho de 2008; a aprovação do Plano Estratégico 2010-2016, em conformidade com a Resolução N. 70 do CNJ; a elaboração do Manual de Redação Oficial do TJDFT; e a implantação do Sistema de Gestão da Qualidade com Certificação ABNT NBR ISO 9001-2008.

\subsection{Satisfação dos usuários}

Com o advento da Reforma Gerencial da Administração Pública, defender o interesse público, oferecer à sociedade um serviço público de qualidade e atender 
às necessidades dos cidadãos devem ser as metas prioritárias a serem buscadas em quaisquer organizações públicas.

Segundo os entrevistados, anteriormente ao Planejamento Estratégico, o Tribunal de Justiça não possuía muita continuidade em suas ações, e não havia movimentação, na Casa, que orientasse todos os colaboradores a uma melhor prestação jurisdicional, e, conseqüentemente, à satisfação do usuário final.

Digamos que a população ficava insatisfeita e não era percebido dentro da Casa um movimento pra mudar isso. Era assim e ia continuar assim: "nós queremos prestar um serviço melhor, mas não temos condições de prestar, não temos servidor, não temos estrutura física, então não dá, vamos esperar". Hoje não. Hoje percebe-se que o Tribunal está se movimentando (ENTREVISTADO B).

Os participantes enfatizaram que a elaboração do Planejamento Estratégico revitalizou a missão e desenhou uma visão de futuro de forma participativa, unificada e integrada, traduzindo-se em maiores benefícios para seus membros e para a sociedade. As ações desenvolvidas, alinhadas à estratégia organizacional, buscaram aperfeiçoar o padrão de qualidade e celeridade nos serviços prestados pelo Tribunal:

Hoje, a destinação de recursos e a implementação de novos projetos são totalmente alinhadas ao Planejamento Estratégico e o alvo a ser atingido é a melhoria na prestação jurisdicional. O impacto disso é imensurável, uma vez que gera um efeito cascata que abrange todo o Tribunal (ENTREVISTADO A).

Então, o que eu vejo hoje como servidora da Casa é que o Planejamento Estratégico contribuiu sobremaneira para o encaixar de peças. $E$ que isso contribui lá na ponta, porque aquele servidor que atende lá no balcão, ele tem que ter a competência de atendimento ao público. E se ele não tem, ele tem que desenvolver. E ele vai desenvolvê-la por quê? Porque está ligada à estratégia da Casa, que quer atender adequadamente e com qualidade (ENTREVISTADO B).

Mas, por exemplo, por trás do planejamento, nós chegamos à informatização do tribunal e isso melhorou demais, tanto pra gente que trabalha quanto pro atendimento, na celeridade, por exemplo. Então eu acho que a maior forma de explicar o que é o planejamento do Tribunal para gente que está aqui na área judiciária e também para a população, o maior exemplo mesmo é a informatização. (...). Então, por trás disso teve um planejamento que nos trouxe tecnologia (...). Agora não é só informatização, é tudo também que está por trás disso: condições de trabalho, salário, mobiliário, material, melhor distribuição dos fóruns, criação de varas, postos de servidores, aumento do número de juízes. Isso tudo está dentro de um planejamento que é naturalmente para a área judiciária e pra instituição de um modo geral (ENTREVISTADO D). 
O TJDFT busca renovar seu modelo de gestão e modernizar os serviços públicos prestados à sociedade do Distrito Federal, adotando instrumentos de planejamento para garantir a melhoria de desempenho e o alcance de metas pré-estabelecidas.

"A organização [pública] deve alinhar suas ações e seus resultados às necessidades e expectativas dos cidadãos e da sociedade. Mais ainda: deve antecipar tais necessidades" (ANDRADE JÚNIOR, 2009, p. 97, grifo nosso).

A grande maioria das ações é voltada para a melhoria da prestação jurisdicional e os impactos na eficiência ao atendimento ao cidadão são cada dia mais visíveis (ENTREVISTADO A).

\begin{abstract}
Na verdade, as coisas aconteceram em conseqüência ao plano estratégico. Depois da elaboração do plano estratégico, aconteceu inclusive uma pesquisa de satisfação na Segunda Instância. O interessante é que ela apontou exatamente pra aquilo que o plano estava trazendo. Na verdade, a gente não teve a participação da sociedade antes para a construção do plano. Mas o interessante é que algumas ações que aconteceram depois comprovaram e mostraram que a gente estava no caminho certo. E hoje 0 que a gente tem acompanhado também, nos resultados da Ouvidoria, é que muitas coisas tem melhorado, muitas precisam melhorar. Mas a gente pelo menos está no rumo. Antes a gente não tinha rumo (ENTREVISTADO B).
\end{abstract}

Os pronunciamentos demonstram que o Tribunal procura conhecer seus stakeholders e busca, continuamente, informações pertinentes a eles. Isso possibilita que a organização responda à altura aos seus interessados externos. (STARIK, 1995 apud HOFFMANN; PROCOPIAK FILHO; ROSSETO, 2008).

Várias iniciativas foram apontadas como medidas paliativas, dentre elas pesquisas de satisfação, realizadas em diversos setores que contribuíram sobremaneira para a melhoria dos serviços prestados.

A cada nova iniciativa de mensurar o nível de satisfação dos usuários quanto à prestação de seus serviços, o TJDFT amadurece e aperfeiçoa sua condição de avaliar sua atuação e de promover melhorias. 


\title{
5 CONCLUSÕES E RECOMENDAÇÕES
}

A missão do Tribunal de Justiça do Distrito Federal e dos Territórios é: "Proporcionar à sociedade do Distrito Federal e dos Territórios o acesso à Justiça e a resolução dos conflitos, por meio de um atendimento de qualidade, promovendo a paz social". Atender aos anseios da sociedade é a prioridade máxima a ser alcançada, vista sob a perspectiva do Balanced Scorecard em instituições públicas.

O objetivo do presente estudo foi o de analisar o instrumento e o processo utilizado pelo TJDFT, na construção do Plano Estratégico, e avaliar o impacto da sua implementação na melhoria da prestação jurisdicional.

Conclui-se, de acordo com os discursos dos entrevistados e com os documentos analisados, que o Planejamento Estratégico impulsionou a organização na melhoria da qualidade dos serviços prestados, por meio do alinhamento entre a instituição e o contexto em que está inserida, desenvolvendo ações que atendem às necessidades do cidadão.

\begin{abstract}
Encerrando mais um ciclo de gestão, não há como se questionar os avanços obtidos nos últimos dois anos. Os resultados, objetivamente mensurados por meio de indicadores, confirmam tais conquistas e representam um grande passo rumo ao aperfeiçoamento do Tribunal de Justiça do Distrito Federal e dos Territórios (DESEMBARGADOR PRESIDENTE LÉCIO RESENDE).
\end{abstract}

Ainda nesse sentido, puderam-se extrair outras duas conclusões:

a) O Planejamento Estratégico possibilita a continuidade das ações.

Vale destacar que uma das grandes fraquezas das organizações públicas é a descontinuidade das ações provocada pela mudança de gestão. Com o surgimento do CNJ no cenário nacional, o estabelecimento das Metas de Nivelamento e o engajamento dos gestores públicos, o Planejamento Estratégico tornou-se a principal ferramenta de combate a esse problema e o foco na prestação jurisdicional ficou mais evidente. O uso da metodologia de planejamento auxilia a mensuração do progresso das organizações rumo a um futuro desejado, a partir da tradução da visão em objetivos, indicadores, metas e projetos estratégicos. 
Estamos em um nível de maturidade satisfatório, é claro que ainda resta muito a melhorar, mas, pelo menos, já temos condições de nos enxergar e ver onde precisa ser melhorado (ENTREVISTADO A).

b) O Planejamento Estratégico oferece foco e direcionamento à organização. Diante dos depoimentos de alguns entrevistados, percebeu-se que as unidades administrativas eram mais "independentes", o que contribuía para um baixo grau de interação entre elas. A utilização da ferramenta de Balanced Scorecard, no processo de implementação do plano, ocasionou na definição do foco a ser seguido e na orientação das unidades administrativas e dos colaboradores em prol de um objetivo comum: prestação jurisdicional com eficiência, qualidade e celeridade. Com isso, atualmente são promovidas diversas ações em conjunto que estão alinhadas à estratégia da Casa.

c) O Planejamento Estratégico proporciona melhor utilização dos recursos.

Os participantes apontaram que o planejamento, alinhado à estratégia do Tribunal, auxilia na melhor alocação dos recursos materiais. O fato de existir um planejamento sistemático e contínuo ajuda na melhor distribuição de materiais de consumo no TJDFT, influenciando, inclusive, a prestação jurisdicional pelo servidor. São desenvolvidos, atualmente, projetos e ações no Tribunal que promovem reaproveitamento de papel, por exemplo, para ajudar na maior disponibilidade de materiais.

Em relação aos recursos financeiros, são realizadas capacitações para os colaboradores que estão diretamente alinhadas à estratégia da Casa, e que, por isso, impactam na otimização dos gastos.

Contudo, foram identificados não apenas ganhos, mas também deficiências no processo. Perante isso, duas conclusões foram ressaltadas:

a) Baixa participação dos servidores do nível operacional.

O conhecimento é, sem dúvida, a principal matéria prima na condução e realimentação do processo de Planejamento. Kaplan e Norton (1997) afirmam que a estratégia é tarefa de todos, reforçando a necessidade do envolvimento e aproveitamento do conhecimento dos diversos níveis da organização na definição e manutenção da estratégia. A disseminação da cultura de planejamento estratégico no TJDFT se mostrou ineficaz, que pode estar 
atrelada, também, à insuficiência de participações do nível operacional no processo como um todo.

Sem orientação estratégica, baseada no conhecimento formal e tácito, torna-se inviável a concentração de forças e recursos no sentido de buscar a excelência na prestação de serviços, meta de qualquer órgão do poder público.

É notório que a área fim não foi totalmente envolvida no processo de Planejamento, como a área meio, fato que contribui para o desconhecimento de aspectos primordiais e que prejudica o desempenho final. Verificou-se que a percepção da área fim, no que se refere à utilização da ferramenta, está voltada, apenas, para a disponibilização de recursos materiais.

Com isso, o envolvimento maior de servidores do nível operacional enriqueceria o produto final que, conseqüentemente, estaria mais alinhado com a realidade da prestação jurisdicional.

b) A interferência política prevalece sobre o conhecimento técnico.

Outro aspecto pertinente, quanto às deficiências no processo de Planejamento Estratégico, é a questão política prevalecer sobre o conhecimento técnico. Muitas vezes, a vontade de alguém importante no nível hierárquico interfere no processo de construção, levando a ações que, segundo opinião técnica, não teriam condições de ser executadas.

No entanto, a atividade de planejamento se configura, cada vez mais, como instrumento de gestão, cujo objetivo principal é subsidiar a tomada de decisão e orientar a atuação das diversas unidades que compõem a estrutura de uma organização.

Vale ressaltar, com base nos pontos expostos, que todas as questões sejam devidamente analisadas nos próximos ciclos de planejamento, de forma que seja possível maior envolvimento de todos os níveis da organização, principalmente o operacional, e que possa prevalecer o conhecimento técnico especializado. Mas que, além disso, sejam realizadas novas pesquisas que possam aprofundar 0 assunto de Planejamento Estratégico no Judiciário, tendo em vista que houve limitação do presente estudo em relação ao número de entrevistados. 


\section{REFERÊNCIAS}

ALMEIDA, Geraldo S.; FONTES FILHO, Joaquim R.; MARTINS, Humberto F. Identificando stakeholders para formulação de estratégias organizacionais. In: XXIV Encontro Nacional dos Programas de Pós-Graduação em Administração, 24., 2000, Florianópolis. Anais... Florianópolis, 2000.

ANDRADE JUNIOR, Sylvio R. Como alcançar a excelência em gestão. In: WEST, Marcos A. M. (Coord.). Gestão estratégica no Ministério da Justiça 2009. Brasília: Secretaria Executiva/MJ, 2009, p. 90-101.

\section{BARACHO, Alexandre J. A adoção e a implementação do planejamento} estratégico: o caso do Poder Judiciário do Estado de Pernambuco, sob a ótica dos seus stakeholders relevantes. 2002. 210 f. Dissertação (Mestrado em Administração) - Centro de Ciências Sociais Aplicadas, Universidade Federal de Pernambuco, Recife, 2002.

BARRETO, Luiz P.; DOSTLER, Peter M. Gestão estratégica na administração pública. In: WEST, Marcos A. M. (Coord.). Gestão estratégica no Ministério da Justiça 2009. Brasília: Secretaria Executiva/MJ, 2009, p. 12-33.

BRASIL. Ministério do Planejamento. Comitê Executivo do Governo Eletrônico. Oficinas de planejamento estratégico. Comitês Técnicos, 23p. Relatórios Consolidados. Disponível em:

<http://www.governoeletronico.gov.br/governoeletronico>. Acesso em: 26 out. 2010.

BRASIL. Emenda constitucional №. 45, de 30 de dezembro de 2004. Lex: legislação federal. Disponível em:

<http://www.planalto.gov.br/ccivil_03/constituicao/emendas/emc/emc45.htm>. Acesso em: 05 nov. 2010

BRASIL. Presidência da República. Cadernos MARE de Reforma do Estado (v. 9; 54p.). Brasília, Ministério da Administração e Reforma do Estado, 1998.

BRESSER PEREIRA, Luiz C. Reforma do Estado para a cidadania: a reforma gerencial brasileira na perspectiva internacional. Brasília: ENAP, 1998.

CANCELLIER, Éverton L. O papel de stakeholders na formulação de estratégias de pequenos empreendimentos catarinenses. Revista de Negócios, Brasil, v. 5, n. 2, 
2000. Disponível em: <http://proxy.furb.br/ojs/index.php/rn/article/viewArticle/404>. Acesso em: 30 out. 2010

CARMAZEN, Júlio. Planejamento estratégico: visão de futuro. Webartigos, 2008. Disponível em: <http://www.webartigos.com/articles/11314/1/PlanejamentoEstrategico-Visao-de-Futuro/pagina1.html>. Acesso em: 20 nov. 2010.

CHAER, Ana Carolina L.; AZEVEDO, Joel S.; BONIFÁCIO, Ivan G. 2009. Projeto de Gestão Estratégica do Poder Judiciário do Brasil. In: Il Congresso CONSAD de Gestão Pública, 2., 2009, Brasília. Anais... Brasíla, 2009.

CHIAVENATO, Idalberto; SAPIRO, Arão. Planejamento Estratégico: fundamentos e aplicações. Rio de Janeiro: Elsevier, 2003.

CONSELHO NACIONAL DE JUSTIÇA. Resolução n. 70. Disponível em:<http://www.cnj.jus.br/images/stories/docs_cnj/resolucao/rescnj_70.pdf>. Acesso em: 03 nov. 2010.

CONSELHO NACIONAL DE JUSTIÇA. Disponível em: <http://www.cnj.jus.br>. Acesso em: 10 out. 2010.

DRUCKER, Peter F. Introdução à administração. São Paulo: Pioneira, 1984.

FREITAS, Carlos A. Elaboração de estratégias em pequenas empresas: um estudo em pequenas empresas dos municípios do litoral norte catarinense. 2010. 183f. Dissertação (Mestrado em Administração) - Universidade do Vale do Itajaí, Biguaçu, Santa Catarina, 2010.

GOMES, Ricardo C. Proposing a research framework for exploring Stakeholder influences in public organizations. 2004. Revista Alcance, Brasil, v. 12 , n. 1, p. 9-26, abr. 2005.

HOFFMANN, Valmir E.; PROCOPIAK FILHO, José A.; ROSSETTO, Carlos R. As estratégias de influência dos stakeholders nas organizações da indústria da construção civil: setor de edificações em Balneário Camboriú - SC. Ambiente Construído, Porto Alegre, v. 8, n. 3, p. 21-35, jul./out. 2008. 
JAUCH, Laurence R.; GLUECK, William F. Business Policy and Strategic Management. 5. ed. [S.I]: McGraw-Hill, 1988.

JOBIM, Nelson. Posse na presidência do Supremo Tribunal Federal. Brasília: 2004. Disponível em:

<http://www.stf.jus.br/arquivo/cms/publicacaoPublicacaolnstitucionalPossePresidenci al/anexo/Plaqueta_de_Posse_Ministro_Nelson_Jobim_na_Presidencia.pdf $>$. Acesso em: 07 nov. 2010.

KAPLAN, Robert S.; NORTON, David P. A estratégia em ação: balanced scorecard. 26. ed. Rio de Janeiro: Elsevier, 1997.

LAKATOS, Eva M.; MARCONI, Marina de A.. Metodologia do Trabalho Científico. 4. ed. São Paulo: Atlas, 1992.

MATUS, Carlos. Política, planejamento e governo. 2 v. Brasília: Ipea, 1988.

MENDES, Gilmar. Pronunciamento do Ministro Gilmar Mendes. Organização do Poder Judiciário Brasileiro. 2009. 13p. Disponível em:

$<$ www.stf.jus.br/arquivo/cms/noticiaArtigoDiscurso/anexo/JudicBrasil.pdf >. Acesso em: 28 out. 2010.

MORAIS, Paulo R. A. de. Planejamento estratégico em tecnologia da informação no Superior Tribunal de Justiça. 2009. 58 f. Monografia (apresentada ao final do curso de Especialização em Contabilidade Pública) - Faculdade de Economia, Administração, Contabilidade e Ciência da Informação e Documentação da Universidade de Brasília, Brasília, 2009.

OLIVEIRA, Djalma de P. R. de. Planejamento estratégico: conceitos, metodologia e práticas. 22. ed. São Paulo: Atlas, 2006.

PEDRO, José M. O balanced scorecard (BSC) no sector público. Informação \& Informática, n. 28, 2004.

PORTO, Cláudio; BELFORT, Andréa. Introdução ao planejamento estratégico institucional. Apostila para o curso de Formação para a Carreira de Analista de Planejamento e Orçamento. MACROPLAN - Prospectiva e Estratégia. Brasília: 2001. 
RAMADAM, Ismael M. G. Análise do desempenho de uma aliança estratégica: um estudo exploratório de empresa brasileira e argentina. 2001. 122f. Programa de Pós-Graduação em Administração - Escola de Administração da Universidade Federal do Rio Grande do Sul, Porto Alegre, 2001.

RELBI. Relatório de Atividades e Resultados do Biênio 2006/2008 do Tribunal de Justiça do Distrito Federal e dos Territórios. Brasília, 2008. Disponível em: $<$ http://www.tjdft.jus.br/trib/gest/docGest/relbi_2006_2008.pdf>. Acesso em: 03 jan. 2011.

RICHARDSON, Roberto Jarry. Pesquisa social: métodos e técnicas. 3. ed. São Paulo: Atlas, 1999.

RUAS, Edgar B. Criação de indicadores estratégicos para o instituto de pesquisas tecnológicas do estado de São Paulo S.A - IPT, RAE-ELETRÔNICA, São Paulo, v. 2, n. 1, jan./jun. 2003. Disponível em:

$<$ http://www16.fgv.br/rae/eletronica/index.cfm?FuseAction=Artigo\&ID=1872\&Secao= 2\%BAPWC\&Volume=2\&Numero=1\&Ano=2003 >. Acesso em: 13 nov. 2010.

RUSSO, Andréa Rezende. Uma moderna gestão de pessoas no Poder Judiciário. 2009. 197 f. Dissertação (Mestrado Profissional em Poder Judiciário) FGV Direito Rio, Rio de Janeiro, 2009.

SADEK, Maria Tereza. Judiciário: mudanças e reformas. Estud. av., São Paulo, v. 18, n. 51, ago. 2004. Disponível em:

<http://www.scielo.br/scielo.php?script=sci_arttext\&pid=S0103-

40142004000200005\&lng=en\&nrm=iso>. Acesso em: 05 nov. 2010.

SILVA, Edna L.; MENEZES, Estera M. Metodologia da Pesquisa e Elaboração de Dissertação. 3. ed. Florianópolis, 2000. Disponível em:

$<$ http://projetos.inf.ufsc.br/arquivos/Metodologia\%20da\%20Pesquisa\%203a\%20edica o.pdf>. Acesso em: 22 nov. 2010.

SUPREMO TRIBUNAL FEDERAL. Relatório de avaliação do Plano Plurianual 2008-2011 do STF. 2009. Disponível em:

<http://www.stf.jus.br/arquivo/cms/administracaoSigplan/anexo/Caderno_Setorial_10 000.pdf>. Acesso em: 05 nov. 2010.

ZIMMERMANN, Neusa de C. Curso de especialização em Gestão Pública.

Disciplina: elaboração e monitoramento de projetos. Fevereiro, 2003. 


\section{APÊNDICES}

\section{Apêndice A - Roteiro de Entrevista}

\section{Dados do entrevistado}

1 Nome

2 Desde quando atua no TJDFT

3 Cargo que ocupa

4 Área Administrativa ou Judiciária

5 Cargo que ocupava em 2007

\section{Questões}

1. Na sua opinião, como era o TJDFT, antes de 2007 , do ponto de vista da sua gestão, estrutura organizacional e visão de futuro?

2. Que fatores foram determinantes para a adoção de um processo de planejamento estratégico na Gestão 2006/2008? Que pessoas, grupos de pessoas, ou órgãos tiveram um papel relevante nesse processo?

3. $\mathrm{O}(\mathrm{A})$ Sr. (a) tem algum conhecimento acerca da influência do CNJ no processo do planejamento estratégico? Como é a sua percepção dessa influência, positiva ou negativa? Explique.

4. É do seu conhecimento se já havia ocorrido, anteriormente, no âmbito do TJDFT, alguma experiência de planejamento estratégico? Se sim, informe, quando e de que forma se deu esse processo.

5. Qual foi a metodologia de planejamento adotada pelo TJDFT? Essa metodologia favoreceu a participação, dos diferentes interessados, ou grupos de interessados (stakeholders) na ação do Poder Judiciário? Se sim, de que forma?

6. Como se deu a construção da Missão, Visão e Valores?

7. Que aceitação teve a metodologia de planejamento estratégico durante a Gestão 2006-2008? Houve conflitos internos devido à sua adoção? Se sim, quais foram e de que forma eles foram tratados? 
8. Na sua opinião, o índice médio de realização dos objetivos e metas contemplados no Plano de Gestão 2006-2008 e 2008-2010 foi satisfatório, ou não? Justifique sua resposta.

9. Como é realizada a construção das metas e indicadores do TJDFT?

10. No Planejamento Estratégico 2010-2016, como está a consecução dos objetivos?

11. Que associação o (a) Sr. (a) faz entre a adoção do planejamento estratégico e o nível de atendimento aos anseios dos cidadãos, no período de 2007-2010? Justifique sua resposta. Como era antes desse período?

12. Na fase de implementação, quais foram os principais fatores de sucesso (aspectos facilitadores) observados? E os principais obstáculos (aspectos dificultadores) encontrados?

13. Como a adoção e a implementação de uma visão estratégica afetaram o equilíbrio de poder até então existente? Como se comportaram os principais atores (stakeholders) envolvidos no processo decisório da instituição?

14. Na sua opinião, ocorreram mudanças e inovações desde a Gestão 2006-2008, em função da adoção do planejamento estratégico? Se sim, cite as mais relevantes e quais os seus impactos sobre o funcionamento do Judiciário.

15. Que fatores devem ser observados, para a consolidação da experiência de planejamento estratégico no TJDFT?

16. $\mathrm{O}(\mathrm{A})$ Sr. (a) acredita que o planejamento estratégico em bem difundido no TJDFT, em todos os seus níveis?

17. É do seu conhecimento se a metodologia do planejamento estratégico era adotada pelo Poder Judiciário de outros Estados, à época? Se sim, cite em quais. Se não, o (a) Sr.(a) tem conhecimento de como a experiência do TJDFT repercutiu nos demais Estados? Se sim, informe o teor dessa repercussão.

18. O (A) Sr. (a) acredita que suas ações, atualmente, estão, de alguma forma, relacionadas com o alcance dos objetivos estratégicos?

19. O (A) Sr. (a) classifica o TJDFT como uma instituição estratégica, que possui missão, visão e objetivos direcionados para a sociedade? 
ANEXOS

\section{Anexo A - Organograma da Presidência do TJDFT}

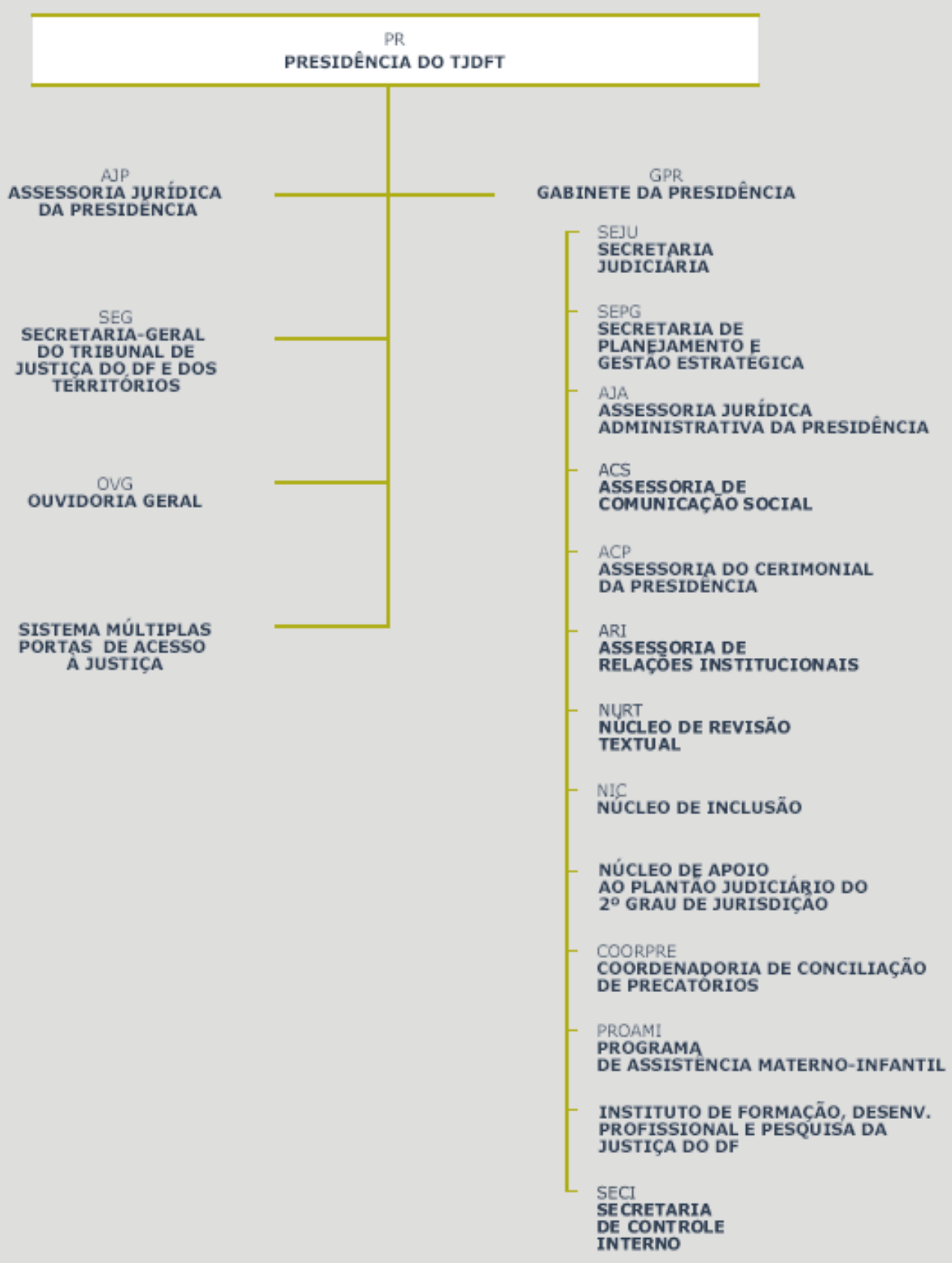




\section{Anexo B - 10 Metas Nacionais de Nivelamento}

As 10 Metas Nacionais de Nivelamento deveriam ser alcançadas pelo judiciário até o final de 2009:

META 1: Desenvolver e/ou alinhar planejamento estratégico plurianual (mínimo de 05 anos) aos objetivos estratégicos do Poder Judiciário, com aprovação no Tribunal Pleno ou Órgão Especial.

META 2: Identificar os processos judiciais mais antigos e adotar medidas concretas para o julgamento de todos os distribuídos até 31/12/2005 (em 1ํㅜ , 2ํㅡㄴ grau ou tribunais superiores).

META3: Informatizar todas as unidades judiciárias e interligá-las ao respectivo tribunal e à rede mundial de computadores (internet).

META 4: Informatizar e automatizar a distribuição de todos os processos e recursos.

META 5: Implantar sistema de gestão eletrônica da execução penal e mecanismo de acompanhamento eletrônico das prisões provisórias.

META 6: Capacitar o administrador de cada unidade judiciária em gestão de pessoas e de processos de trabalho, para imediata implantação de métodos de gerenciamento de rotinas.

META 7: Tornar acessíveis as informações processuais nos portais da rede mundial de computadores (internet), com andamento atualizado e conteúdo das decisões de todos os processos, respeitado o segredo de justiça.

META 8: Cadastrar todos os magistrados como usuários dos sistemas eletrônicos de acesso a informações sobre pessoas e bens e de comunicação de ordens judiciais (Bacenjud, Infojud, Renajud).

META 9: Implantar núcleo de controle interno.

META 10: Implantar o processo eletrônico em parcela de suas unidades judiciárias. 


\section{Anexo C - Resolução CNJ no. 70, de 18 de março de 2009}

Dispõe sobre o Planejamento e a Gestão Estratégica no âmbito do Poder Judiciário e dá outras providências.

O PRESIDENTE DO CONSELHO NACIONAL DE JUSTIÇA, no uso de suas atribuições constitucionais e regimentais, e

CONSIDERANDO competir ao Conselho Nacional de Justiça, como órgão de controle da atuação administrativa e financeira dos tribunais, a atribuição de coordenar o planejamento e a gestão estratégica do Poder Judiciário;

CONSIDERANDO a unicidade do Poder Judiciário, a exigir a implementação de diretrizes nacionais para nortear a atuação institucional de todos os seus órgãos;

CONSIDERANDO que os Presidentes dos tribunais brasileiros, reunidos no I Encontro Nacional do Judiciário, deliberaram pela elaboração de Planejamento Estratégico Nacional, a fim de aperfeiçoar e modernizar os serviços judiciais;

CONSIDERANDO o trabalho realizado nos 12 (doze) Encontros Regionais, consolidado no Plano Estratégico apresentado e validado no II Encontro Nacional do Judiciário, realizado em 16 de fevereiro de 2009, na cidade de Belo Horizonte-MG;

CONSIDERANDO a aprovação, no II Encontro Nacional do Judiciário, de 10 Metas Nacionais de Nivelamento para o ano de 2009;

CONSIDERANDO a necessidade de se conferir maior continuidade administrativa aos tribunais, independentemente das alternâncias de seus gestores;

CONSIDERANDO determinar a Resolução CNJ n.ำ 49, de 18 de dezembro de 2007, a criação de Núcleo de Estatística e Gestão Estratégica, unidade administrativa competente para elaborar, implementar e gerir o planejamento estratégico de cada órgão da Justiça;

RESOLVE: 


\section{CAPÍTULO I \\ DO PLANEJAMENTO E DA GESTÃO ESTRATÉGICA \\ DISPOSIÇÕES GERAIS}

Art. 1ํ Fica instituído o Planejamento Estratégico do Poder Judiciário, consolidado no Plano Estratégico Nacional constante do Anexo I desta Resolução, sintetizado nos seguintes componentes:

I - Missão: realizar justiça.

II - Visão: ser reconhecido pela Sociedade como instrumento efetivo de justiça, equidade e paz social.

III - Atributos de Valor do Judiciário para a Sociedade:

a) credibilidade;

b) acessibilidade;

c) celeridade;

d) ética;

e) imparcialidade;

f) modernidade;

g) probidade;

h) responsabilidade Social e Ambiental;

i) transparência.

IV - 15 (quinze) objetivos estratégicos, distribuídos em 8 (oito) temas:

a) Eficiência Operacional:

Objetivo 1. Garantir a agilidade nos trâmites judiciais e administrativos;

Objetivo 2. Buscar a excelência na gestão de custos operacionais;

b) Acesso ao Sistema de Justiça:

Objetivo 3. Facilitar o acesso à Justiça;

Objetivo 4. Promover a efetividade no cumprimento das decisões; 
c) Responsabilidade Social:

Objetivo 5. Promover a cidadania;

d) Alinhamento e Integração:

Objetivo 6. Garantir o alinhamento estratégico em todas as unidades do Judiciário;

Objetivo 7. Fomentar a interação e a troca de experiências entre Tribunais nos planos nacional e internacional;

e) Atuação Institucional:

Objetivo 8. Fortalecer e harmonizar as relações entre os Poderes, setores e instituições;

Objetivo 9. Disseminar valores éticos e morais por meio de atuação institucional efetiva;

Objetivo 10. Aprimorar a comunicação com públicos externos;

f) Gestão de Pessoas:

Objetivo 11. Desenvolver conhecimentos, habilidades e atitudes dos magistrados e servidores;

Objetivo 12. Motivar e comprometer magistrados e servidores com a execução da Estratégia;

g) Infraestrutura e Tecnologia:

Objetivo 13. Garantir a infraestrutura apropriada às atividades administrativas e judiciais;

Objetivo 14. Garantir a disponibilidade de sistemas essenciais de tecnologia de informação;

h) Orçamento:

Objetivo 15. Assegurar recursos orçamentários necessários à execução da estratégia; 
Art. $2^{\circ}$ O Conselho Nacional de Justiça e os tribunais indicados nos incisos II a VII do Art. 92 da Constituição Federal elaborarão os seus respectivos planejamentos estratégicos, alinhados ao Plano Estratégico Nacional, com abrangência mínima de 5 (cinco) anos, bem como os aprovarão nos seus órgãos plenários ou especiais até 31 de dezembro de 2009.

$\S 1^{\circ}$ Os planejamentos estratégicos de que trata o caput conterão:

I - pelo menos um indicador de resultado para cada objetivo estratégico;

II - metas de curto, médio e longo prazos, associadas aos indicadores de resultado;

III - projetos e ações julgados suficientes e necessários para o atingimento das metas fixadas.

$\S 2^{\circ}$ Os tribunais que já disponham de planejamentos estratégicos deverão adequálos ao Plano Estratégico Nacional, observadas as disposições e requisitos do caput e do $\S 1^{\circ}$ deste artigo.

$\S 3^{\circ}$ As propostas orçamentárias dos tribunais devem ser alinhadas aos seus respectivos planejamentos estratégicos, de forma a garantir os recursos necessários à sua execução.

§ 4ํㅡㄴ Os tribunais garantirão a participação efetiva de serventuários e de magistrados de primeiro e segundo graus, indicados pelas respectivas entidades de classe, na elaboração e na execução de suas propostas orçamentárias e planejamentos estratégicos.

§ 5ㅇ O disposto no parágrafo anterior não se aplica aos tribunais superiores, sem prejuízo da participação efetiva de ministros e serventuários na elaboração e na execução de suas estratégias.

§ 6을 Conselho Nacional de Justiça adotará as providências necessárias para fornecer auxílio técnico-científico aos tribunais na elaboração e na gestão da estratégia.

Art. 3ํำ Núcleo de Gestão Estratégica dos tribunais ou unidade análoga coordenará ou assessorará a elaboração, implementação e gestão do planejamento estratégico, como também atuará nas áreas de gerenciamento de projetos, otimização de 
processos de trabalho e acompanhamento de dados estatísticos para gestão da informação.

$\S 1^{\circ}$ Os tribunais deverão priorizar, inclusive nas suas propostas orçamentárias, a estruturação dos Núcleos de Gestão Estratégica ou unidade análoga.

§ 2ํ O Conselho Nacional de Justiça encaminhará aos tribunais, por intermédio do Departamento de Gestão Estratégica, sugestão de estruturação das atividades dos Núcleos de Gestão Estratégica.

\author{
CAPÍTULO III \\ DO BANCO DE BOAS PRÁTICAS DE GESTÃO \\ DO PODER JUDICIÁRIO
}

Art. 4ํ O Conselho Nacional de Justiça manterá disponível no seu Portal na Rede Mundial de Computadores (internet) o Banco de Boas Práticas de Gestão do Poder Judiciário, a ser continuamente atualizado, com o intuito de promover a divulgação e o compartilhamento de projetos e ações desenvolvidos pelos tribunais.

$\S 1^{\circ}$ Os projetos e ações do Banco de Boas Práticas de Gestão do Poder Judiciário serão subdivididos de acordo com os temas da Estratégia Nacional, a fim de facilitar a identificação pelos tribunais interessados na sua utilização.

$\S 2^{\circ}$ Os projetos e práticas a serem incluídos no Banco de Boas Práticas de Gestão do Poder Judiciário devem ser encaminhados ao Departamento de Gestão Estratégica do Conselho Nacional de Justiça, órgão responsável pela sua gestão.

\title{
CAPÍTULO IV
}

DO ACOMPANHAMENTO DOS RESULTADOS

Art. 5 Os tribunais promoverão Reuniões de Análise da Estratégia - RAE trimestrais para acompanhamento dos resultados das metas fixadas, oportunidade em que 
poderão promover ajustes e outras medidas necessárias à melhoria do desempenho.

\section{CAPÍTULO V}

DOS INDICADORES, METAS E PROJETOS NACIONAIS

Art. 6 Sem prejuízo do planejamento estratégico dos órgãos do Poder Judiciário, o Conselho Nacional de Justiça coordenará a instituição de indicadores de resultados, metas, projetos e ações de âmbito nacional, comuns a todos os tribunais.

Parágrafo Único. As metas nacionais de nivelamento para o ano de 2009 estão descritas no Anexo II desta Resolução.

\section{CAPÍTULO VI}

\section{DAS DISPOSIÇÕES FINAIS}

Art. $7^{\circ}$ Compete à Presidência do Conselho Nacional de Justiça, em conjunto com a Comissão de Estatística e Gestão Estratégica, assessorados pelo Departamento de Gestão Estratégica, coordenar as atividades de planejamento e gestão estratégica do Poder Judiciário.

Parágrafo Único. A Presidência do Conselho Nacional de Justiça instituirá e regulamentará Comitê Gestor Nacional para auxiliar as atividades de planejamento e gestão estratégica do Poder Judiciário, a ser coordenado pelo Presidente da Comissão de Estatística e Gestão Estratégica.

Art. 8ํㅡㄹ Esta Resolução entra em vigor na data de sua publicação.

Ministro Gilmar Mendes

Presidente 


\section{Anexo D - 10 Metas Prioritárias de 2010}

As 10 metas prioritárias que o Judiciário deve atingir no ano de 2010 são as seguintes:

META 1: julgar quantidade igual à de processos de conhecimento distribuídos em 2010 e parcela do estoque, com acompanhamento mensal;

META 2: julgar todos os processos de conhecimento distribuídos (em $1^{\circ} \mathrm{grau}$, $2^{\circ}$ grau e tribunais superiores) até 31 de dezembro de 2006 e, quanto aos processos trabalhistas, eleitorais, militares e da competência do tribunal do Júri, até 31 de dezembro de 2007;

META 3: reduzir em pelo menos $10 \%$ o acervo de processos na fase de cumprimento ou de execução e, em 20\%, o acervo de execuções fiscais (referência: acervo em 31 de dezembro de 2009);

META 4: lavrar e publicar todos os acórdãos em até 10 dias após a sessão de julgamento;

META 5: implantar método de gerenciamento de rotinas (gestão de processos de trabalho) em pelo menos $50 \%$ das unidades judiciárias de $1^{\circ}$ grau;

META 6: reduzir a pelo menos $2 \%$ o consumo per capita com energia, telefone, papel, água e combustível (ano de referência: 2009);

META 7: disponibilizar mensalmente a produtividade dos magistrados no portal do tribunal;

META 8: promover cursos de capacitação em administração judiciária, com no mínimo 40 horas, para 50\% dos magistrados;

META 9: ampliar para 2 Mbps a velocidade dos links entre o Tribunal e 100\% das unidades judiciárias instaladas na capital e, no mínimo, 20\% das unidades do interior;

META 10: realizar, por meio eletrônico, 90\% das comunicações oficiais entre os órgãos do Poder Judiciário. 